
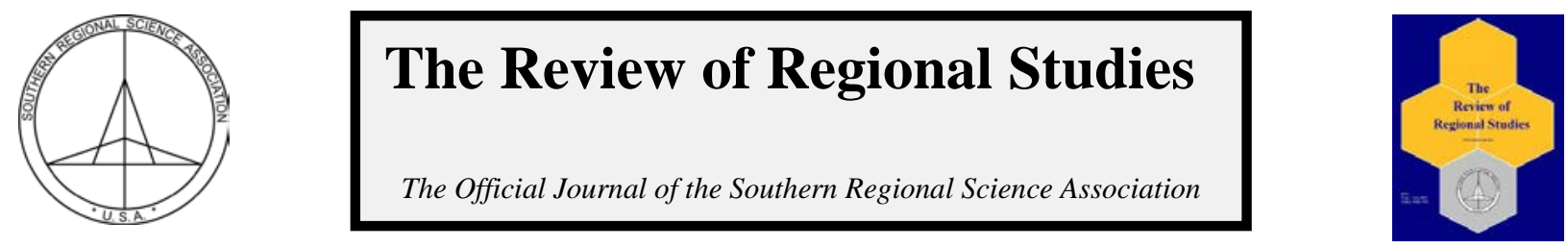

\title{
Are More Severe Recessions Followed by Stronger Early Expansions of Employment in the Mexican States?*
}

\author{
Pablo Mejía-Reyes and Reyna Vergara-González \\ Centro de Investigación en Ciencias Económicas, Faculty of Economics, Universidad Autónoma del Estado de México, México
}

\begin{abstract}
This paper estimates conventional linear models to evaluate whether the average growth rate of employment (permanent, temporary, and total) over early expansions depends on the characteristics of prior recessions for the Mexican states during the 2001 and 2008 recessions. After controlling for the initial impulse of external and fiscal shocks as well as for the effects of structural factors, our results suggest that the depth and steepness of prior recessions (measured as the percentage accumulated drop and monthly average growth rate) have negative effects on employment growth over the first 9 and 12 months following the 2001 recession. In contrast, employment growth in the aftermath of the 2008 recession can be explained primarily by external and fiscal shocks. In general, the duration of recessions has no effect on employment growth after recessions.
\end{abstract}

Keywords: employment, regional business cycles, recessions, expansions

JEL Codes: E24, E32, R11

\section{INTRODUCTION}

The severity and worldwide spread of the Great Recession, as well as the weakness and uncertainty of the current world recovery, have called the attention of researchers to the dynamics of business cycle regimes. For example, regarding the current expansion, Dominguez and Shapiro (2013) analyze the effects of domestic fiscal policies and financial mechanisms as well as the role of shocks emanating from Europe. Bordo and Haubrich (2012) study the effects of residential investment in the case of the U.S. Elwell (2013) investigates the causes of the weakness of private spending, while Abiad et al. (2009) focuses on the role of impaired financial systems and external imbalances in several economies.

Although there may be multiple factors conditioning the dynamics of expansions, a branch of the literature has focused on the analysis of economic activity over their initial stages. ${ }^{1}$ According to an old idea advanced by Friedman $(1969,1993)$ and Moore (1965), a recovery can be stronger than the rest of this phase and its intensity may be negatively associated with the

*E-mails: pmejiar@yahoo.co.uk, and reyna_vg@yahoo.com, respectively. Phone number: +52 7222149411. The authors acknowledge the comments from two anonymous referees as well as financial support from the National Council of Science and Technology (CONACYT) of Mexico, through the research grant with key number CB2012/182471. In addition, they thank Dayana Silva-Jaimes and Virginia N. del Campo-Sánchez for excellent research assistance. As usual, all remaining errors and omissions are responsibility of the authors.

1 These analyses were based on the classical view of the business cycle introduced by Mitchell (1927) and Burns and Mitchell (1946), who understand the cycle as the alternation of phases (or regimes) of expansions and recessions.

(c) Southern Regional Science Association 2017.

ISSN 1553-0892, 0048-749X (online)

www.srsa.org/rrs 
magnitude of the prior recession. ${ }^{2}$ In their view, the dynamics of this process can be thought of as a self-corrective response to low economic activity and, consequently, as an endogenous response of the system. This relationship is commonly referred to as the "bounce-back" effect.

Regarding the empirical evidence, this phenomenon has rarely been examined in the literature. Balke and Wynne (1994) study whether early stages of expansions differ from the rest of that phase, while Wynne and Balke (1992, 1993) and Balke and Wynne (1995) examine that the severity of a recession favorably affects the growth rate of output during the subsequent recovery. In general, these authors report evidence that supports the hypothesis of a "bounce-back" effect in the cases of the U.S. and the G-7 countries, results that contrast with those reported by Cerra et al. (2013) for different groups of countries.

Alternatively, some papers analyze the capacity of an economic system to recover from the impact of exogenous shocks, a phenomenon known as resilience (Martin, 2012), while others measure the effects of recessions on the long-run growth rate of the economy (Kannan, Scott, and Terrones, 2014; Souvik and Jacques, 2009). Although related, these processes differ from the one analyzed in this paper since they refer to the medium- or long-run responses of the economy. Moreover, all these studies analyze the effects of recessions on subsequent expansions in different countries, but none of them has paid attention to the experience of their states or regions. This is the concern of this paper and, in that sense, it can be inscribed in the so-called intra-national macroeconomics.

In the case of Mexico, there are some studies addressing the characteristics and synchronization of the state classical business cycles. ${ }^{3}$ Erquizio $(2006,2008)$ combines different variables to obtain monthly composite indexes to represent the business cycle of several Mexican states, while Erquizio (2011) builds annual indexes to measure the characteristics of the recessions of 1995, 2001-2003, and 2008-2009. Mejía (2007) and Mejía and Erquizio (2012) use the same approach to identify state expansions and recessions and to measure regime asymmetries in terms of mean, volatility, and duration. In addition, even if they report a moderate synchronization across the state cycle regimes, their result suggest that there has been an increasing synchronization of the national cycle regimes with those of the U.S. economy, especially during the North American Free Trade Agreement (NAFTA) era. On the other hand, Delajara (2013) estimates a high degree of co-movement between the classical cycle regimes of formal employment in 12 states, out of the 32, located on the northern border with the U.S., the western-central, and the central regions of the country. He claims that the sources of these fluctuations seem to be shocks to national employment. Finally, Erquizio and Ramírez (2014) analyze the Great Recession effects as well as the magnitude of the subsequent expansion across the Mexican states by building state cyclical indexes inspired in the classical view of the cycle. Their results suggest that state recessions were deeper and expansions were stronger where manufacturing production represented a higher proportion of total output.

Although these papers have contributed to a better understanding of the regional business cycle regime characteristics, the relationship between recessions and expansions has not been explicitly analyzed in the case of Mexico. Therefore, the aim of this paper is to measure the effects

\footnotetext{
2 Sometimes "contraction" and "recovery" are used instead of "recession" and "expansion” in this literature. We adopt these denominations in this paper.

${ }^{3}$ This brief literature review only includes analyses of regional business cycles based on the classical approach since it underlies the ideas of Moore (1965) and Friedman $(1969,1993)$.
}

(c) Southern Regional Science Association 2017. 
of duration (in months), depth (accumulated fall), and steepness (monthly average growth rate) of the recessions of 2001-2003 and 2008-2009 on the growth rates of the initial stages of the subsequent expansions (referred to here as early expansions) for the 32 Mexican states. We carry out our analysis using different measures of formal employment as indicators of economic activity to characterize recessions and expansions. We find evidence of a negative association between recession depth and steepness and the average growth rate of employment observed over the first 9 and 12 months that followed the 2001 recession, but not in the aftermath of the 2008 recession, after controlling for the initial impulse of external and fiscal shocks and the effects of structural factors.

The rest of this paper is organized as follows. Section 2 offers a brief review of the theoretical literature addressing the effects of recessions on expansions, while Section 3 describes the methodology to identify the business cycle regimes and their characteristics as well as the econometric methodology to be used. Section 4 presents and discusses the results. In the final section, some conclusions are stated.

\section{SOME THEORETICAL CONSIDERATIONS}

The analysis of the effects of recessions on expansions is based on the classical view of the business cycle introduced by Mitchell (1927) and Burns and Mitchell (1946). This approach defines the cycle as a succession of two alternate phases of sustained decline in real economic activity, or recessions, followed by episodes of sustained increases in the economic indicators, or expansions (Boldin, 1994; Artis et al., 1997). ${ }^{4}$

Regarding the theoretical literature, it is accepted that the dynamics of recoveries can be complex and their magnitude and intensity can be explained by multiple factors. Some time ago, Moore (1965) and Friedman $(1969,1993)$ proposed the possibility that deeper contractions could be followed by stronger recoveries. In particular, by focusing on the first months of a recovery, Moore (1965) reports three stylized facts. First, there exists a negative relationship between a contraction and the subsequent recovery, which depends on the magnitude of the former (e.g. a severe recession yields a vigorous recovery, and vice versa). Second, the average growth rates over the initial months of a recovery are greater when they are preceded by deeper recessions. Third, the growth rates of the first 6 and 12 months of a recovery are greater than those of the subsequent periods and the growth rates of the last 12 months of a recovery are smaller than those of the first 12 months. This relationship is known as the "bounce-back" effect (Wynne and Balke 1992).

Despite the notion of a "bounce-back" effect that may be intuitively attractive, it has not been explicitly addressed in most models of business cycles, even if the mechanics of growth in the initial stages of an expansion is implicit in some of them. For example, Friedman $(1969,1993)$ argued that contractions are the result of random perturbations in demand that take the economy temporarily away from its long-run level of production. ${ }^{5}$ Thus, a negative shock would cause a fall in economic activity and generate excess capacity, which, in turn, would favor fast recoveries before the inexistence of restrictions in the use of the productive factors. Since deeper contractions imply greater capacity excess, they will be followed by faster recoveries due to the "bounce-back"

\footnotetext{
${ }^{4}$ This view differs from the one proposed by Lucas (1977) where the (growth) cycle is defined as the gross national product fluctuations around its underlying trend, without distinguishing any phase or regime.

${ }^{5}$ However, although this level is limited upward by capacity constraints, it may increase over time as the economy accumulates resources and incorporates technological advances.
}

(c) Southern Regional Science Association 2017. 
effect. In this model, high growth rates during recoveries are related to inventory replenishment implemented by firms to face the eventual expansion of demand. In that sense, this process may be seen as a self-corrective response of the system to low economic activity. By using another analogy, Friedman (1969) called this the "plucking model." 6

In turn, in a standard real business cycle model, which assumes rational economic agents and competitive markets, cyclical fluctuations are caused by exogenous random technological shocks hitting constantly and taking the economy away from its long-run equilibrium growth path (King, Plosser, and Rebelo 1988). In that sense, negative shocks generate recessions, with falls in production, consumption, investment, employment, and other variables, and vice versa. Then, a recovery from a recession can be seen as the return of the economy to its steady state equilibrium and its dynamics would be essentially the same as the transitional dynamics of the standard neoclassical growth model. Therefore, it is expected that the economy will grow faster the farther the capital stock is from its long-run equilibrium level. Consequently, large technology shocks that provoke significant reductions in the capital stock should be immediately followed by periods of vigorous growth.

Other models have also tried to explain the relationship between recessions and growth. In line with the ideas of Schumpeter (1939), the creative destruction models claim that technological change involves wide historical and irreversible processes of innovation as well as the reallocation of productive factors across sectors, ${ }^{7}$ which modifies the economic structure, destroying old firms and creating new ones (Tichy, 2011). Moreover, expansions caused by technological changes actually constitute deviations from the long-run equilibrium position and, in a sense, they become disproportionate, discontinuous, and inharmonic processes that generate cyclical fluctuations. Hence, contractions are not only a reaction of the system to the distortions generated by expansions, but they are also a process of adaptation of the existing firms to more difficult conditions implied by technological progress. In this logic, a more vigorous economy may emerge from recessions because obsolete and unproductive firms are expelled from the system (the "cleansing effect") while entrant firms ought to operate at higher levels of efficiency (Caballero and Hammour, 1994; Aghion and Saint-Paul, 1991). In the end, this process may generate higher output growth rates. In general, brief and deep recessions, characterized by a significant destruction of firms and job positions, may be followed by periods of rapid output growth.

\section{EMPIRICAL METHODOLOGY}

The estimation of the effects of recession characteristics on the growth rates of early expansions in the Mexican states consists of two stages. The first stage relates to the identification and characterization of the business cycle regimes, whilst the second refers to the econometric estimation of those effects. The recession and expansion regimes are identified and characterized by applying the classical business cycle methodology introduced by Artis at al. (1997), AKO hereafter. In general, it consists of a set of censoring rules to exclude short-run erratic fluctuations and focus the attention on broad upward (expansion) and downward (recession) movements of the variable of interest, generally a measure of output or employment. Its main advantage is that it is based only on a univariate analysis, allowing the identification of specific regimes for the variable

\footnotetext{
${ }^{6}$ Friedman provides empirical support for this view. However, his results do not show an analogous effect from prior strong recoveries on subsequent recessions, a fact that exhibits an asymmetric relationship across the business cycle regimes.

${ }^{7}$ A process of innovation involves not only new technologies (embedded in the production function), but also new products, novel forms of organization, new markets, incumbent firms, and new personnel (Hansen 1965).
}

(C) Southern Regional Science Association 2017. 
of interest, whilst its relevance has been proved by the fact that it yields turning points very close to those defined by the National Bureau of Economic Research (NBER) for the U.S. economy (Artis et al., 1997). ${ }^{8}$

Once it is identified, a recession can be characterized in terms of three properties: duration, measured by the number of time periods between a peak and a trough, depth (amplitude), measured by the accumulated percentage drop in the values of the variable over the recession, and steepness, measured by the average growth rate over the course of the same regime. It is also possible to compute the average growth rates over the first $k(=9,12)$ months of expansions. Furthermore, we return to the classical concept of recovery (revival in the original terminology of Burns and Mitchell (1946)), which can be defined as the early stage of an expansion that goes from the trough up to the point where the value of the variable at the previous peak is obtained. $k$ equals the number of time periods needed for this to happen. ${ }^{9}$ Then, although we distinguish these recoveries, in general we refer to the initial months of expansions as early expansions.

In the second stage, the effects of recession characteristics on early expansion growth are estimated based on the model suggested by Wynne and Balke (1992) and Balke and Wynne (1995). In particular, they estimate the following relationship,

$$
\boldsymbol{l}_{\boldsymbol{i}}(\boldsymbol{k})=\alpha+\beta \boldsymbol{s}_{\boldsymbol{i}}+\gamma\left(\boldsymbol{T}_{\boldsymbol{i}}-\boldsymbol{P}_{\boldsymbol{i}}\right)+\delta\left(\boldsymbol{y}_{\boldsymbol{T}_{\boldsymbol{i}}}-\boldsymbol{y}_{\boldsymbol{P}_{\boldsymbol{i}}}\right)+\boldsymbol{u}_{\boldsymbol{i}}
$$

where $i$ denotes the $i$ th state; $l_{i}(k)$ is the average monthly growth rate of employment during the first $k$ months of the expansion; $s_{i}$ is the measure of steepness; $P$ is the date of the peak defining the beginning of the recession and $T$ is the date of the trough denoting its end; $y$ stands for the natural logarithm of employment, ${ }^{10}$ while $u_{i}$ is a disturbance term that follows a white noise process. Therefore, the average growth rate of employment over the first $k$ months of an expansion can be explained by the steepness of the prior recession $\left(s_{i}\right)$, its duration in months $\left(T_{i}-P_{i}\right)$, and its depth $\left(y_{i T}-y_{i P}\right)$. In particular, if steepness is the most relevant explanatory factor, it is expected that $\beta$ will be negative and significant. If, on the other hand, duration is the important determinant, $\gamma$ would be positive, implying that longer recessions favor stronger recoveries. Finally, if deeper recessions precede stronger early expansions, $\delta$ would be negative and significant.

We extend this formulation to avoid possible specification errors. First, due to their construction, there may be some degree of collinearity between depth and duration, on the one hand, and steepness, on the other. ${ }^{11}$ Therefore, these variables are included separately as regressors.

Second, even if rapid growth over early expansions can be seen as a self-corrective response of the system to low economic activity, as suggested by Friedman (1969, 1993), output revivals may actually be caused by external or policy shocks. In particular, the international literature has shown that trade has acted as a central mechanism in the transmission of shocks from one country to others, contributing to the synchronization of their business cycles (Baxter and Kouparitsas, 2005; Kose and Yi, 2001). Hence, given the high degree of synchronization of the

\footnotetext{
${ }^{8}$ See Moore and Zarnowitz (1986) and Boldin (1994) for additional information on the role of the NBER.

${ }^{9}$ This may be the phase that Friedman and Moore had in mind since it is related to the existence of capacity excess.

${ }^{10}$ More specifically, for example, $y_{T i}$ refers to the log of employment at the date of the trough.

${ }^{11}$ Formally, steepness = depth/duration. However, they are not necessarily identical. For example, a large depth can be associated to a long recession generating a low steepness, and vice versa.
}

(c) Southern Regional Science Association 2017. 
business cycles of Mexico and the U.S. (Mejía and Campos, 2011), the recuperation of the latter's economy may have pulled the former's out of a recession by means of a greater demand for exports, affecting positively the growth rate of the tradable goods sector $\left(t_{i}\right)$. In addition, some authors have argued that fiscal policies can affect the cyclical dynamics of the economy (Fatás and Mihov, 2000), especially during recessions (Auerbach and Gorodnichenko, 2013), while others have analyzed the same subject at a regional level (Miyazaki, 2013; Rodden and Wibbels, 2010). In Mexico, the central government followed a countercyclical fiscal policy in an attempt to mitigate the effects of the Great Recession mainly through increases in the growth rate of the federal government expenditure, $g_{i}$ (see Villagómez and Navarro, 2010).

Third, the growth rate of state employment over early expansions can also be affected by a set of structural factors. On the one hand, the capacity of a state to recover from recessions (an idea related to the concept of resilience) may be linked to the GDP per capita growth rate (Lavender and Parent, 2013) since this can be seen as an indicator of long-run potential growth. ${ }^{12}$ On the other hand, the ability of the economy to react to a variety of shocks may be positively associated with its degree of exposure to external shocks (measured as the ratio of tradable to non-tradable goods production or the ratio of industrial to services production) or the mobility of its labor force (measured by the net migration rate). Such an association could exist because both may reflect how flexible the economy is to changing circumstances (UKCES, 2014). ${ }^{13}$

Fourth, geographical location may be important in the magnitude of the recuperation of employment: the closer to the U.S. market a state is, the greater its employment growth rate over early expansions. Two measures of geographical location are used in this paper: the distance (in kilometers) from the capital city of each state to the nearest important U.S. city, namely San Diego (California), El Paso, or San Antonio (Texas) and a dummy variable to represent the location of a specific state on the border with the U.S. ${ }^{14}$

Therefore, the model specifications are as follows:

$$
\begin{gathered}
\boldsymbol{l}_{\boldsymbol{i}}(\boldsymbol{k})=\alpha+\gamma\left(\boldsymbol{T}_{\boldsymbol{i}}-\boldsymbol{P}_{\boldsymbol{i}}\right)+\delta\left(\boldsymbol{y}_{\boldsymbol{T}_{\boldsymbol{i}}}-\boldsymbol{y}_{\boldsymbol{P}_{\boldsymbol{i}}}\right)+\varphi \boldsymbol{t}_{\boldsymbol{i}}+\omega \boldsymbol{g}_{\boldsymbol{i}}+\boldsymbol{x}_{\boldsymbol{i}} \boldsymbol{\theta}+\boldsymbol{u}_{\boldsymbol{i}} \\
\boldsymbol{l}_{\boldsymbol{i}}(\boldsymbol{k})=\alpha+\beta \boldsymbol{s}_{\boldsymbol{i}}+\varphi \boldsymbol{t}_{\boldsymbol{i}}+\omega \boldsymbol{g}_{\boldsymbol{i}}+\boldsymbol{x}_{\boldsymbol{i}} \boldsymbol{\theta}+\boldsymbol{u}_{\boldsymbol{i}}
\end{gathered}
$$

Equation (2), which we will also refer to as Model A, relates the average growth rate of employment during the first $k$ months of an expansion to recession duration and depth, while Equation (3), which we shall refer to as Model B, does so for recession steepness. Both models include the growth rates of federal government expenditures and the tradable goods sector ${ }^{15}$ of the year when expansions started (trough year) to capture the initial impulse of the shocks. It is expected that external shocks will have positive effects on the production of tradable goods and, therefore, on employment recovery $(\varphi>0)$. While the sign of the coefficient of $g_{i}$ may be positive or negative depending on the actual effects of the fiscal policy followed across the Mexican states. If $g_{i}$ was pro-cyclical during the trough year, then $\omega>0$ because employment and government

\footnotetext{
${ }^{12}$ GDP per capita growth rates may also measure the variations of population well-being, which in turn may be associated to amenities, a central variable in the analysis of Rickman and Guettabi (2015).

${ }^{13}$ Variables measuring structural factors are computed as averages over the five years prior to each recession.

${ }^{14}$ Empirical evidence suggests that the synchronization of the business cycles with the U.S. cycle is higher in the case of the Mexican states located in the Northern border or in the Center-North and Center regions (Mejía and Campos, 2011).

15 The tradable goods sector includes agriculture, livestock, forestry, fishing, hunting, mining, manufacturing, temporary accommodation, and preparation of food and beverage services.
}

(c) Southern Regional Science Association 2017. 
expenditure would be simultaneously falling, and vice versa. In addition, each model incorporates a set of variables associated to regional structural characteristics of the states (vector $x_{i}$ with vector of coefficients $\theta$ ).

\section{RECESSION CHARACTERISTICS AND RECOVERIES: EMPIRICAL EVIDENCE}

\subsection{U.S. and Mexican Business Cycles and Recessions: Some General Facts}

We use the methodologies described in the previous section to estimate the effects of the recessions experienced by the Mexican economy in 2001-2003 and 2008-2009 (2001 recession and 2008 recession, hereafter) on the subsequent early expansions. As it is well known, these recessions originated in the U.S. and propagated to the rest of the world, ${ }^{16}$ especially to its main trade partners and foreign investment receptors, like Mexico, given their high degree of economic integration.

Since the mid-eighties, the Mexican authorities followed an ambitious process of reforms to modernize the economy, including foreign trade and investment liberalization, re-privatization of public firms, and deregulation of markets (Aspe, 1993; Moreno-Brid and Ros, 2009). Accordingly, the Mexican economy transitioned to an open, market-oriented economy, which caused it to become more sensitive to external shocks (Sosa, 2008). Therefore, manufacturing exports to the U.S. and investments from the U.S. grew at exponential rates (Kose, Meredith, and Towe, 2004; Tornell, Westermann and Martínez, 2004). These ties provoked the aggregate business cycles of both economies to become increasingly synchronized, especially after the North American Free Trade Agreement (NAFTA) came into force in 1994, as several studies have reported (Gutiérrez, Mejía, and Cruz, 2005; Ramírez and Castillo 2009; Mejía and Erquizio, 2012). ${ }^{17}$ Hence, the quick and rather violent transmission of the last two U.S. recessions to the Mexican economy was not surprising.

Table 1 shows the main properties of these episodes in Mexico, dated using the AKO methodology and two measures of output. Based on quarterly Gross Domestic Product (GDP) and the monthly Global Indicator of Economic Activity (GIEA), the recessions are characterized in terms of their duration, depth, and steepness. ${ }^{18}$ Regarding duration, the first recession started in Mexico in 2000.08 (2000.III) and lasted for 19 months (6 quarters), while in the U.S., according to the NBER, the peak was in 2001.03 (2001.I) with a duration of 8 months (3 quarters). This timing and the difference in duration gives evidence of the high sensitivity of the Mexican economy not only to declines in the U.S. economic activity, but also to its deceleration. In turn, the second Mexican recession started in 2008.03 (2008.II) and ended in 2009.05 (2009.II), with a duration of 14 months (4 quarters). Interestingly, although the recession started earlier in the U.S., 2007.12, and lasted for 18 months (6 quarters), it was highly synchronized with the Mexican one. ${ }^{19}$

\footnotetext{
${ }^{16}$ For analyses of the causes and consequences of these recessions, see Nordhaus (2002), Kliesen (2003), Blanchard (2009), and Imbs (2009).

${ }^{17}$ Indeed, although there is still some debate, it is evident that the regimes of the Mexican and U.S. business cycles lacked synchronization during the 1980s and the first half of the 1990s (Mejía, 1999; Mejía, 2004).

${ }^{18}$ It is important to note that in Mexico there is not official business cycle turning point dates. However, the National Institute of Statistics and Geography (INEGI) has recently reported a Coincident Index that tries to capture the performance of the unobserved business cycle. For these recessions, the turning point dates are: a peak in August 2000 and a trough in September 2003, and a peak in April 2008 and a trough in June 2009, respectively. These dates differ from those reported in Table 1, but they are largely consistent with those obtained when disaggregated measures of output, like industrial or manufacturing production (Mejía and Erquizio, 2012), or employment are used,.

${ }^{19}$ Mejía and Erquizio (2012) analyze the transmission and effects of these recessions on the Mexican economy.
} 
Table 1: Characteristics of Recessions and Early Expansions of Mexican Production

\begin{tabular}{|c|c|c|c|c|c|c|c|c|c|c|c|}
\hline \multicolumn{6}{|c|}{ GIEA } & \multicolumn{6}{|c|}{ GDP } \\
\hline \multicolumn{3}{|c|}{ Recession } & \multicolumn{3}{|c|}{ Early expansion* } & \multicolumn{3}{|c|}{ Recession } & \multicolumn{3}{|c|}{ Early expansion* } \\
\hline Depth & Steepness & Duration & EG9 & EG12 & EGR & Depth & Steepness & Duration & EG3T & EG4T & EGRT \\
\hline \multicolumn{6}{|c|}{2001} & \multicolumn{6}{|c|}{2001} \\
\hline-3.48 & -0.22 & 16 & 0.33 & 0.205 & 0.2 & -1.97 & -0.33 & 6 & 0.56 & 0.48 & 0.615 \\
\hline \multicolumn{6}{|c|}{2008} & \multicolumn{6}{|c|}{2008} \\
\hline-8.15 & -0.77 & 11 & 0.61 & 0.641 & 0.6 & -6.66 & -1.71 & 4 & 1.69 & 1.61 & 1.467 \\
\hline \multicolumn{12}{|c|}{$\begin{array}{l}\text { * Average growth rates. GIEA stands for the (monthly) Global Indicator of Economic Activity and GDP for (quarterly) } \\
\text { Gross Domestic Product. In turn, EG9 (EG3T) and EG12 (EG4T) represent the average growth rates during the first } 9 \text { ( } 3 \text { ) } \\
\text { and } 12 \text { (4) months (quarters) over the course of the subsequent expansion and EGR (EGRT) is the average growth rate } \\
\text { over the (classical) recovery. The peak dates of the recessions of } 2001 \text { and } 2008 \text { are 2000/09 (2000-III) and 20008/06 } \\
\text { (2008-II), respectively. }\end{array}$} \\
\hline
\end{tabular}

The measures of the Mexican recession depth and steepness, on the other hand, show that the 2008 recession was more severe with output falls and growth rate declines that more than doubled those of the 2001 recession. For example, the GIEA experienced an accumulated fall of 3.5 percent during the former and a drop of 8.1 percent over the latter. The corresponding figures of GDP are 2.0 and 6.6 percent, respectively. Meanwhile, a comparison of the figures of the two involved countries reveal that during the 2001 recession, the U.S. GDP actually did not fall at all; instead, it had an accumulated growth equal to 1.8 percent over the recession period. On the contrary, over the 2008 recession the same variable presented an accumulated drop of 2.3 percent, a figure that barely exceeds one third of the drop of the Mexican GDP. Thus, it is evident that even if both recessions originated in the U.S. economy, their effects were magnified when transmitted to the Mexican economy.

\subsection{National and State Employment in Mexico: Recession Characteristics and Early Expansions}

As mentioned above, in this paper the recessions and recoveries of the Mexican states are characterized in terms of the dynamics of formal employment. We use this characterization not only because of its high degree of co-movement with different business cycle indicators, as Mejía (2003) and Antón (2011) have shown at a national level, but also due to the availability and consistency of the data. In fact, formal employment is the only measure related to economic activity available for the whole set of 32 Mexican states over this time period (1998-2013).

Formal employment is defined as the number of employed workers who have a job covered by market regulations and social security (pensions and benefits) or the right to a minimum wage; ${ }^{20}$ it is classified in permanent and temporary employment. It is said that a worker has permanent employment when he has a working relationship for an indefinite period of time, while he has temporary employment when that relationship is for a previously specified activity or period of

\footnotetext{
${ }^{20}$ Formal employment represents around 41 percent of the employed population and is closely related to production with a correlation coefficient between their growth rates equal to 0.75 over the period 1998-2013. In turn, although the informal employment share is significant (59 percent of the employed population), available data (for the period 2000-2013) show that it has a low association with output: the correlation between its growth rates and those of the GIEA is equal to 0.28. Furthermore, over the last recession, while the GIEA had an accumulated decline of 8.2 percent, informal employment presented an accumulated growth of 2.2 percent. Moreover, data of informal employment are available at state level only for the period 2010-2014.
}

(c) Southern Regional Science Association 2017. 
time. Overall, permanent workers earn higher wages, have access to training programs, enjoy annual vacations, receive a year-end bonus, and have access to corporate profits, among other benefits. In contrast, temporary workers usually earn lower wages, work for definite short periods of time, and do not receive most of the other benefits, which generates precarious jobs characterized by high instability and uncertainty.

Between 2001 and 2010 in Mexico, most total employment, 91.4 percent, was classified as permanent, while 8.4 percent was considered as temporary. ${ }^{21}$ Over this period, the average growth rates of permanent and total employment were 3.0 percent, while the generation of temporary jobs grew at an average rate of 3.9 percent. Consequently, the temporary employment shares in total employment increased by 1 percentage point, from 8.4 to 9.4 percent. In turn, according to the figures shown in Table 2, total employment is concentrated in the traditional centers of production located in the states of Mexico (MEX), Jalisco (JAL), Nuevo León (NL), and Distrito Federal (DF), whose joint share in the national employment is around 40 percent. ${ }^{22}$ On the other hand, the composition of total employment shows high heterogeneity since the share of permanent employment ranges from around 77 to 96 percent, with the industrialized and Northern bordering states having higher proportions. Interestingly, over this period employment grew faster in states associated with the production of oil (Campeche, CAMP, and Tabasco, TAB) and tourism (Baja California Sur, BCS, Colima, COL, Nayarit, NAY, and Quintana Roo, QROO). In a similar manner to what happened at the national level, the temporary employment average growth rate (5.0 percent) was also greater than that of permanent employment (1.3) across the states, which yielded an average rate of 1.7 percent for the total.

Turning point dates for the national (NAT) employment cycles are identified using the AKO methodology and are reported in Appendix 1. For illustrative purposes, the business cycle regimes of the national employment are depicted in Figure 1 together with the regimes of the U.S. and the Mexican economies. The vertical black lines indicate the beginning (peaks) and ending (troughs) of U.S. recessions, while the vertical gray lines do so for the Mexican recessions, according to the turning points reported by Mejía and Erquizio (2012). In general, the turning points suggested by these authors are very similar to those reported here, although there are some minor differences. ${ }^{23}$

Figure 1 also presents the performance of employment after the troughs indicating the end of each recession. In general, it is apparent that the growth rates during the first 9 (EG9) and 12 (EG12) months over the subsequent expansions and over the recovery (EGR) are greater in the case of the Great Recession, suggesting a negative relationship between the recession depth and the average growth rate over the early stages of the expansion.

Similar conclusions can be drawn from the figures in Table 1 when comparing the monthly (quarterly) growth rates of the GIEA (GDP) over the first 9 and 12 months (3 and 4 quarters) and over the recovery: it is evident that larger falls in output (depth) were followed by greater

\footnotetext{
${ }^{21}$ Data were obtained from the web site of the Mexican Institute of Social Security (www.imss.gob.mx). The series were seasonally adjusted by using the Census X-12 ARIMA method in EViews 8.0.

${ }^{22}$ Table 2 also shows the notation for national employment (NAT) and for the 32 states.

${ }^{23}$ Mejía and Erquizio (2012) apply the AKO methodology to the national manufacturing production and identify the following turning points for the analyzed recessions: a peak in August 2000, a trough in August 2003, and a peak in April 2008 and a trough in May 2009, respectively. These dates are very close to those implied by the Coincident Index of INEGI, but differ from the ones reported in Table 1 obtained using GDP and the GIEA as measures of output.
}

(c) Southern Regional Science Association 2017. 
Table 2: Characteristics of State Employment in Mexico, 2000-2010

\begin{tabular}{|c|c|c|c|c|c|c|c|c|c|}
\hline \multirow[t]{3}{*}{ States } & \multirow{2}{*}{\multicolumn{2}{|c|}{$\begin{array}{c}\text { Share of state in } \\
\text { national } \\
\text { employment } \\
\text { Total }\end{array}$}} & \multicolumn{4}{|c|}{$\begin{array}{l}\text { Percentage structure of state } \\
\text { employment }\end{array}$} & \multicolumn{3}{|c|}{ Average annual growth rate } \\
\hline & & & \multicolumn{2}{|c|}{ Permanent } & \multicolumn{2}{|c|}{ Temporary } & \multirow{2}{*}{$\begin{array}{c}\text { Total } \\
2001- \\
2010 \\
\end{array}$} & \multirow{2}{*}{$\begin{array}{c}\text { Permanent } \\
\text { 2001- } \\
2010 \\
\end{array}$} & \multirow{2}{*}{$\begin{array}{l}\text { Temporary } \\
\text { 2001-2010 } \\
\end{array}$} \\
\hline & 2000 & 2007 & 2000 & 2007 & 2000 & 2007 & & & \\
\hline National (NAT) & 100 & 100 & 90.4 & 88.9 & 9.6 & 11.1 & 1.7 & 1.3 & 5.0 \\
\hline Aguascalientes (AGS) & 1.5 & 1.5 & 92.8 & 91.5 & 7.2 & 8.5 & 1.3 & 1.1 & 4.1 \\
\hline Baja California (BC) & 4.9 & 4.6 & 94.6 & 92.8 & 5.4 & 7.2 & 0.4 & 0.2 & 5.1 \\
\hline Baja California (BCS) & 0.6 & 0.9 & 82.4 & 78.8 & 17.6 & 21.2 & 3.8 & 3.4 & 6.1 \\
\hline Campeche (CAMP) & 0.6 & 0.8 & 77.2 & 78.6 & 22.8 & 21.4 & 4.6 & 5.0 & 3.8 \\
\hline Chiapas (CHIS) & 1.1 & 1.2 & 87.3 & 90.6 & 12.7 & 9.4 & 4.0 & 4.1 & 3.7 \\
\hline Chihuahua (CHI) & 5.7 & 4.8 & 95.7 & 94.0 & 4.3 & 6.0 & -0.9 & -1.3 & 5.5 \\
\hline Coahuila (COAH) & 4.1 & 3.7 & 92.5 & 91.6 & 7.5 & 8.4 & 0.9 & 0.5 & 5.3 \\
\hline Colima (COL) & 0.6 & 0.7 & 82.3 & 85.0 & 17.7 & 15.0 & 3.5 & 3.6 & 3.4 \\
\hline City of Mexico (DF) & 17.8 & 17.6 & 92.7 & 90.6 & 7.3 & 9.4 & 1.5 & 0.9 & 6.8 \\
\hline Durango (DGO) & 1.4 & 1.2 & 92.9 & 90.8 & 7.1 & 9.2 & 0.2 & -0.2 & 5.3 \\
\hline Guanajuato (GTO) & 4.1 & 4.1 & 89.5 & 90.0 & 10.5 & 10.0 & 2.3 & 2.1 & 3.3 \\
\hline Guerrero (GRO) & 1.0 & 1.0 & 82.9 & 79.5 & 17.1 & 20.5 & 1.6 & 1.2 & 3.7 \\
\hline Hidalgo (HGO) & 1.2 & 1.1 & 88.9 & 83.7 & 11.1 & 16.3 & 1.3 & 0.5 & 6.9 \\
\hline Jalisco (JAL) & 8.3 & 8.4 & 90.6 & 90.9 & 9.4 & 9.1 & 2.0 & 1.9 & 3.9 \\
\hline Michoacán (MICH) & 1.9 & 2.1 & 90.3 & 87.7 & 9.7 & 12.3 & 3.4 & 2.9 & 7.6 \\
\hline Morelos (MOR) & 1.2 & 1.2 & 89.5 & 88.0 & 10.5 & 12.0 & 1.8 & 1.5 & 4.7 \\
\hline Mexico (MEX) & 8.1 & 8.2 & 89.0 & 85.2 & 11.0 & 14.8 & 1.8 & 1.0 & 6.8 \\
\hline Nayarit (NAY) & 0.6 & 0.7 & 81.0 & 81.1 & 19.0 & 18.9 & 3.3 & 3.4 & 3.2 \\
\hline Nuevo Leon (NL) & 7.5 & 7.8 & 92.5 & 91.3 & 7.5 & 8.7 & 2.4 & 2.0 & 6.3 \\
\hline Oахаса (OAX) & 1.0 & 1.1 & 88.6 & 89.0 & 11.4 & 11.0 & 2.3 & 2.2 & 3.5 \\
\hline Puebla (PUE) & 3.4 & 2.9 & 90.8 & 88.9 & 9.2 & 11.1 & 0.6 & 0.0 & 5.2 \\
\hline Queretaro (QRO) & 1.9 & 2.2 & 86.0 & 83.3 & 14.0 & 16.7 & 3.7 & 3.1 & 7.1 \\
\hline $\begin{array}{l}\text { Quintana Roo } \\
\text { (QROO) }\end{array}$ & 1.3 & 1.8 & 89.5 & 85.0 & 10.5 & 15.0 & 4.9 & 3.8 & 12.9 \\
\hline San Luis Potosi (SLP) & 1.8 & 2.0 & 87.1 & 85.7 & 12.9 & 14.3 & 2.9 & 2.6 & 5.5 \\
\hline Sinaloa (SIN) & 2.4 & 2.7 & 87.2 & 83.4 & 12.8 & 16.6 & 2.8 & 2.5 & 5.0 \\
\hline Sonora (SON) & 3.0 & 3.0 & 88.8 & 88.0 & 11.2 & 12.0 & 1.9 & 1.7 & 3.6 \\
\hline Tabasco (TAB) & 0.9 & 1.0 & 82.9 & 83.2 & 17.1 & 16.8 & 4.1 & 4.1 & 4.2 \\
\hline $\begin{array}{l}\text { Tamaulipas } \\
\text { (TAMPS) }\end{array}$ & 4.2 & 4.0 & 88.0 & 88.8 & 12.0 & 11.2 & 0.6 & 0.6 & 0.9 \\
\hline Tlaxcala (TLAX) & 0.6 & 0.5 & 93.3 & 89.1 & 6.7 & 10.9 & -0.9 & -2.2 & 10.2 \\
\hline Veracruz (VER) & 4.4 & 4.4 & 83.3 & 84.5 & 16.7 & 15.5 & 2.0 & 2.0 & 2.4 \\
\hline Yucatan (YUC) & 1.9 & 1.9 & 92.9 & 91.9 & 7.1 & 8.1 & 1.6 & 1.5 & 3.0 \\
\hline Zacatecas (ZAC) & 0.8 & 0.8 & 89.9 & 87.8 & 10.1 & 12.2 & 3.1 & 2.4 & 8.4 \\
\hline
\end{tabular}

Source: own elaboration with data from the Mexican Institute of Social Security (www.imss.gob.mx).

growth rates. Nonetheless, a formal estimation of these relationships is required; this is the task to be done next.

The turning points and the characteristics of recessions as well as the average growth rates over the early stages of expansions (EG9, EG12 and EGR) for the 32 states are reported in Appendix 1. A summary is shown in Table 3.

In general, it can be observed that the recession of 2008 was deeper on average than that of 2001 and that the average growth rates over the course of early expansions were greater in the 
Figure 1: Business Cycle Regimens of Different Mexican Employment Indicators

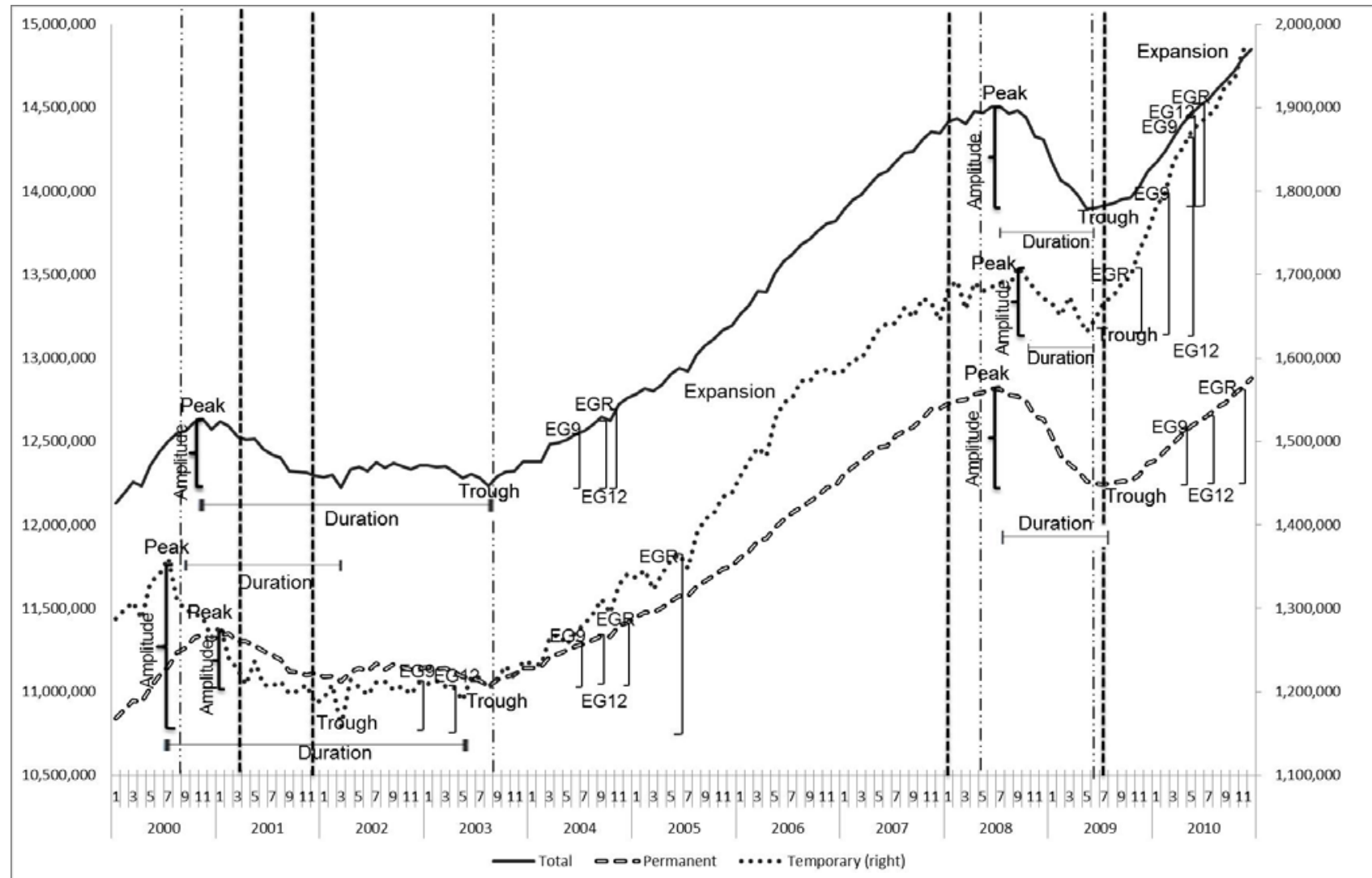

See footnotes of Table 1 for the notation regarding recoveries.

Source: own elaboration with information from IMSS.

former case. In particular, there seems to be a negative relationship between recession depth and steepness and the average growth rates during early expansions in the cases of total and permanent employment in 2001 and 2008. Additionally, other statistics of the growth rate of total employment (such as the minimum and the median of the average growth rate) show that the most recent recession was more severe and more heterogeneous (based on standard deviations) across the states, while the skewness and kurtosis reflect the importance of large drops in employment (negative outliers). Furthermore, the statistics of permanent employment show a similar pattern.

On the other hand, a less clear picture emerges from the dynamics of temporary employment: its larger drops (as measured by the mean, median, and minimum average growth rate) during the 2001 recession (compared with that of 2008) were not followed by greater average growth rates. In addition, its volatility (measured by its standard deviation) was larger during the 2001 recession and greater than that of total and permanent employment in both recessions. The greater heterogeneity across states during the first recession was also accompanied by larger drops, as suggested by a negative skewness and a kurtosis greater than 3 .

One aspect that calls our attention is the fact that the average drop of temporary employment was larger during the 2001 recession than during the Great Recession. In fact, given that the former was a rather shallow recession at the national level while the latter has been the deepest recession over the last 75 years, this result seems to be quite surprising. However, it is important to consider that apart from the rigidity that characterizes the Mexican labor market, 
Table 3: Characteristics of Recessions and Employment Recoveries in the Mexican States

\begin{tabular}{|c|c|c|c|c|c|c|c|c|c|c|c|c|}
\hline & \multicolumn{6}{|c|}{2001} & \multicolumn{6}{|c|}{2008} \\
\hline & \multicolumn{3}{|c|}{ Recession } & \multicolumn{3}{|c|}{ Early expansion* } & \multicolumn{3}{|c|}{ Recession } & \multicolumn{3}{|c|}{ Early expansion* } \\
\hline & Depth & Steepness & Duration & EG9 & EG12 & EGR & Depth & Steepness & Duration & EG9 & EG12 & EGR \\
\hline \multicolumn{13}{|c|}{ Total Employment } \\
\hline Mean & -4.89 & -0.33 & 17.28 & 0.36 & 0.33 & 0.32 & -5.55 & -0.48 & 12.59 & 0.44 & 0.44 & 0.44 \\
\hline Median & -3.18 & -0.30 & 13.50 & 0.30 & 0.22 & 0.25 & -4.54 & -0.45 & 10.00 & 0.42 & 0.42 & 0.38 \\
\hline Maximum & 0.00 & 0.00 & 40.00 & 1.67 & 1.31 & 1.01 & 0.00 & 0.00 & 55.00 & 0.90 & 0.87 & 0.89 \\
\hline Minimum & -15.78 & -1.79 & 0.00 & 0.09 & 0.03 & 0.07 & -15.86 & -0.98 & 0.00 & 0.09 & 0.14 & 0.19 \\
\hline Std. Dev. & 4.02 & 0.32 & 12.97 & 0.30 & 0.28 & 0.22 & 4.25 & 0.28 & 11.10 & 0.20 & 0.19 & 0.19 \\
\hline Skewness & -1.10 & -3.06 & 0.33 & 2.87 & 2.06 & 1.49 & -0.99 & -0.14 & 2.34 & 0.49 & 0.65 & 0.78 \\
\hline $\begin{array}{l}\text { Kurtosis } \\
\text { Jarque- }\end{array}$ & 3.47 & 14.98 & 1.63 & 12.42 & 7.07 & 4.80 & 3.18 & 2.08 & 9.18 & 2.82 & 3.09 & 2.73 \\
\hline Bera & 0.04 & 0.00 & 0.21 & 0.00 & 0.00 & 0.00 & 0.07 & 0.54 & 0.00 & 0.52 & 0.33 & 0.19 \\
\hline \multicolumn{13}{|c|}{ Permanent Employment } \\
\hline Mean & -4.05 & -0.28 & 16.06 & 0.26 & 0.25 & 0.25 & -5.11 & -0.39 & 12.28 & 0.36 & 0.34 & 0.40 \\
\hline Median & -2.22 & -0.17 & 11.00 & 0.19 & 0.19 & 0.21 & -3.86 & -0.34 & 12.00 & 0.34 & 0.31 & 0.32 \\
\hline Maximum & 0.00 & 0.00 & 54.00 & 0.65 & 0.58 & 0.64 & 0.00 & 0.00 & 52.00 & 0.72 & 0.74 & 1.40 \\
\hline Minimum & -16.13 & -2.48 & 0.00 & 0.05 & 0.04 & -0.02 & -19.01 & -0.99 & 0.00 & 0.02 & 0.03 & 0.03 \\
\hline Std. Dev. & 4.53 & 0.47 & 15.96 & 0.16 & 0.15 & 0.15 & 4.64 & 0.26 & 9.74 & 0.17 & 0.17 & 0.29 \\
\hline Skewness & -1.13 & -3.63 & 0.66 & 1.00 & 0.76 & 0.61 & -1.30 & -0.41 & 2.01 & 0.32 & 0.39 & 1.94 \\
\hline $\begin{array}{l}\text { Kurtosis } \\
\text { Jarque- }\end{array}$ & 3.34 & 17.13 & 2.15 & 2.83 & 2.53 & 2.88 & 4.27 & 2.62 & 9.82 & 2.75 & 2.94 & 6.68 \\
\hline Bera & 0.03 & 0.00 & 0.19 & 0.07 & 0.19 & 0.37 & 0.00 & 0.58 & 0.00 & 0.73 & 0.67 & 0.00 \\
\hline \multicolumn{13}{|c|}{ Temporary Employment } \\
\hline Mean & -23.23 & -1.40 & 23.50 & 1.25 & 1.08 & 1.07 & -14.49 & -1.26 & 14.81 & 1.22 & 1.25 & 1.43 \\
\hline Median & -21.64 & -1.25 & 18.50 & 0.93 & 0.98 & 1.00 & -14.51 & -1.29 & 12.00 & 1.09 & 1.17 & 1.11 \\
\hline Maximum & 0.00 & 0.00 & 59.00 & 3.16 & 2.52 & 2.55 & 0.00 & 0.00 & 42.00 & 3.23 & 3.23 & 4.63 \\
\hline Minimum & -52.47 & -4.50 & 0.00 & 0.44 & 0.06 & 0.20 & -30.35 & -3.18 & 0.00 & 0.02 & 0.42 & 0.31 \\
\hline Std. Dev. & 10.51 & 0.88 & 14.43 & 0.66 & 0.59 & 0.63 & 7.77 & 0.76 & 9.89 & 0.78 & 0.63 & 1.00 \\
\hline Skewness & -0.82 & -1.47 & 0.51 & 1.02 & 0.40 & 0.92 & -0.25 & -0.85 & 0.98 & 0.72 & 1.32 & 1.70 \\
\hline Kurtosis & 4.49 & 5.98 & 2.33 & 3.47 & 2.48 & 2.96 & 2.18 & 3.38 & 3.42 & 3.39 & 4.68 & 5.49 \\
\hline $\begin{array}{l}\text { Jarque- } \\
\text { Bera }\end{array}$ & 0.04 & 0.00 & 0.37 & 0.05 & 0.54 & 0.11 & 0.54 & 0.13 & 0.07 & 0.23 & 0.00 & 0.00 \\
\hline
\end{tabular}

* Average growth rates. See footnotes of Table 1 for the notation regarding growth rates over early expansions.

Source: own calculations on the basis of data of IMSS.

temporary employment cuts may have been the most important strategy adopted by firms to face not only the international recession, but also the entry of China into the World Trade Organization in 2001. Therefore, it seems that firms have adopted the substitution of permanent by temporary employment as a strategy to gain competitiveness since the Great Recession.

In turn, this preliminary evidence suggests that longer recessions have not been associated with stronger recoveries. In fact, the longer 2001 recession was followed by lower average growth rates during the first 9 and 12 months of the subsequent expansions, while the shorter 2008 recession was linked to stronger recoveries in the average. 
To characterize their spatial distribution, the average growth rates of state employment over the first 9 months of expansions are presented in Maps 1 to 6. We have arbitrarily defined 0.5 and 1.0 as the limits of the intervals represented in the maps in order to have a sensible distribution of the figures within them and to be able to compare the maps.

The first aspect to highlight relates to the fact that the growth rates of permanent and total employment are lower than those of temporary employment, which causes most figures in the former two cases to lie in the lower interval (Maps 1 to 4). On the contrary, most growth rates of temporary employment lie within the middle and upper intervals in Maps 5 and 6. More specifically, it can be observed in Maps 1 to 4 that greater growth rates were more frequent after the 2008 recession in total employment, and in some sense in permanent jobs, a pattern that is less clear in the case of temporary employment since both recessions were followed by high growth rates. Therefore, in general, there does not seem to be a clear-cut relationship between recessions and early expansions, but a more formal evaluation of this hypothesis is needed.

\subsection{Recession Characteristics and Recoveries: An Econometric Estimation}

The effects of recession characteristics on growth over the subsequent early expansions are estimated by ordinary least squares on the basis of Models A and B. The results are reported in Tables 4, 5, and 6; the estimated models have been tested for an adequate specification: the normality (Jarque-Bera) and heteroskedasticity (Breusch-Pagan) statistic tests have been estimated for each model; the corresponding $p$-values are reported in parenthesis in the same tables. In general, there is no evidence of specification problems, although it has been necessary to correct some models for non-normality caused by the existence of some large positive residuals (outliers) that deliver leptokurtic and positively skewed distributions. The problem was solved by using dummy variables for the specific states associated with those large residuals (a standard deviation greater than three). The estimated coefficients of the dummy variables were always positive and statistically significant (see notes at the bottom of the tables for details). ${ }^{24}$

In general, although the explanatory power of the econometric models (measured by $\bar{R}^{2}$ ) is highly variable, with low values when most explanatory variables are not statistically significant, the results show that recession depth and steepness, to some degree, are significantly associated with the early expansions average growth rates of employment in some Mexican states. Specifically, depth (Model A) has statistically significant (usually at the 5 percent level of significance) and negative effects on the three kinds of employment over the first 9 and 12 months (EG9 and EG12) of the expansion that followed the 2001 recession. Steepness (Model B) seems to be relevant only over the first 9 months (EG9) in the cases of permanent and total employment.

In general, these effects vanish over the (classical) recoveries, which usually take more time. A comparison of the magnitudes of the estimates shows that temporary employment seems to be more sensitive to recession depths than the other types of employment, which may not be surprising given that firms can adjust temporary employment more easily as a function of the business cycle phase the economy is in. Notably, there are no effects of the recession depth and steepness on the growth rates in the aftermath of the 2008 recession. Furthermore, the duration of recessions had no effects on growth in any case. Therefore, there is some evidence that supports the hypothesis of the plucking model in the case of the 2001 recession, but not in the 2008

\footnotetext{
${ }^{24}$ Some states did not experience output drops during recessions (as seen in Appendix 1), but they were not excluded to gain degrees of freedom in the estimation process. In those cases, the characteristics of recessions were set equal to 0.
}

(C) Southern Regional Science Association 2017. 
Map 1: Total Employment Average Growth Rate over the First 9 Months of Expansions (EG9T1), 2001

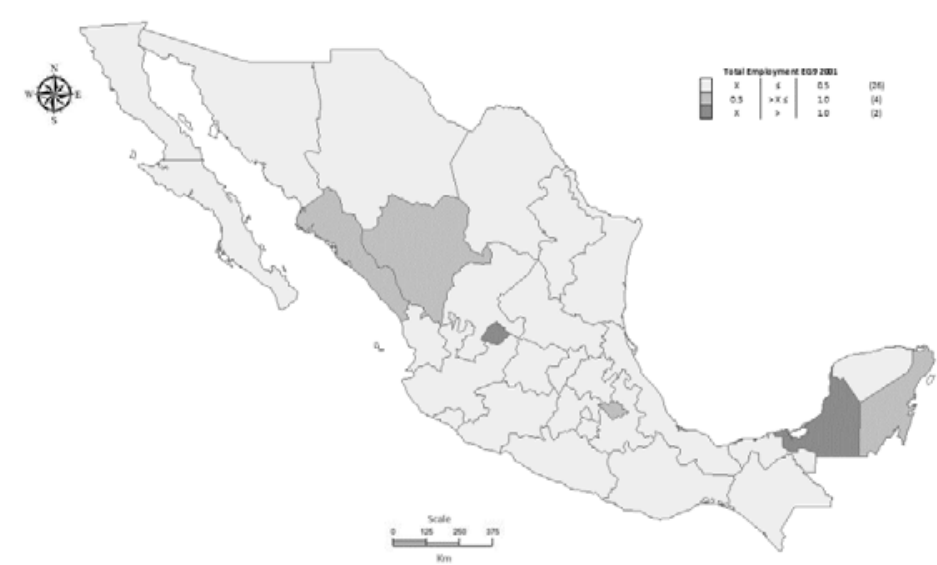

Source: own elaboration with information of the IMSS.

Map 3: Permanent Employment Average Growth Rate over the First 9 Months of Expansions (EG9P1), 2001

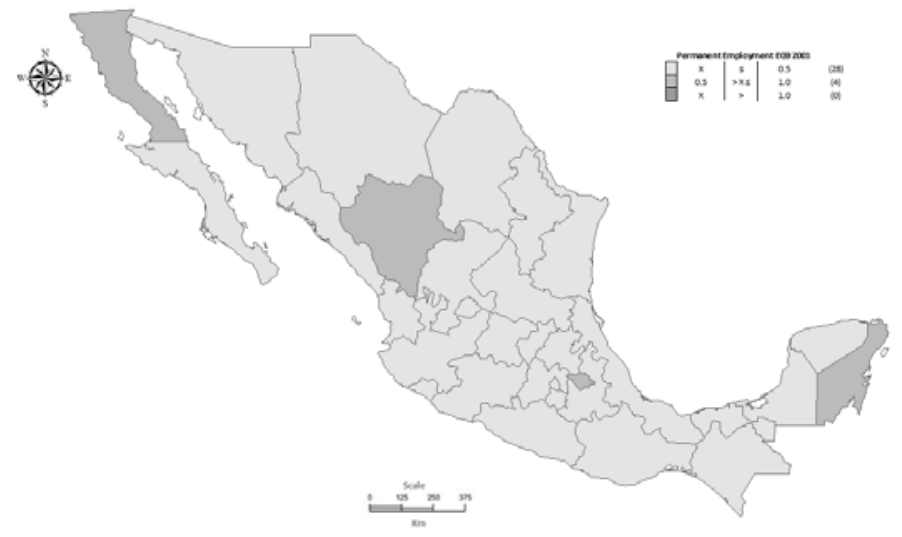

Source: own elaboration with information of the IMSS.
Map 2: Total Employment Average Growth Rate over the First 9 Months of Expansions (EG9T8), 2008

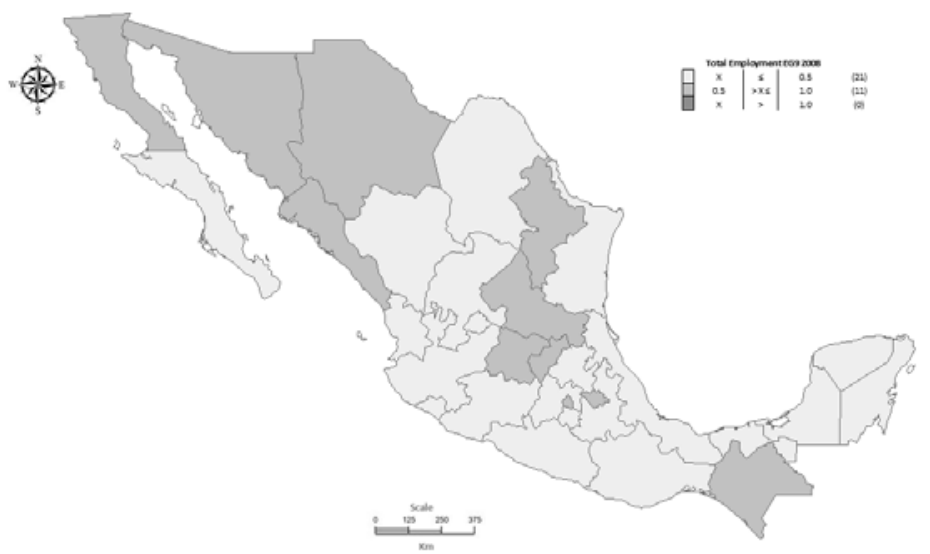

Source: own elaboration with information of the IMSS.

Map 4: Permanent Employment Average Growth Rate over the First 9 Months of Expansions (EG9P8), 2008

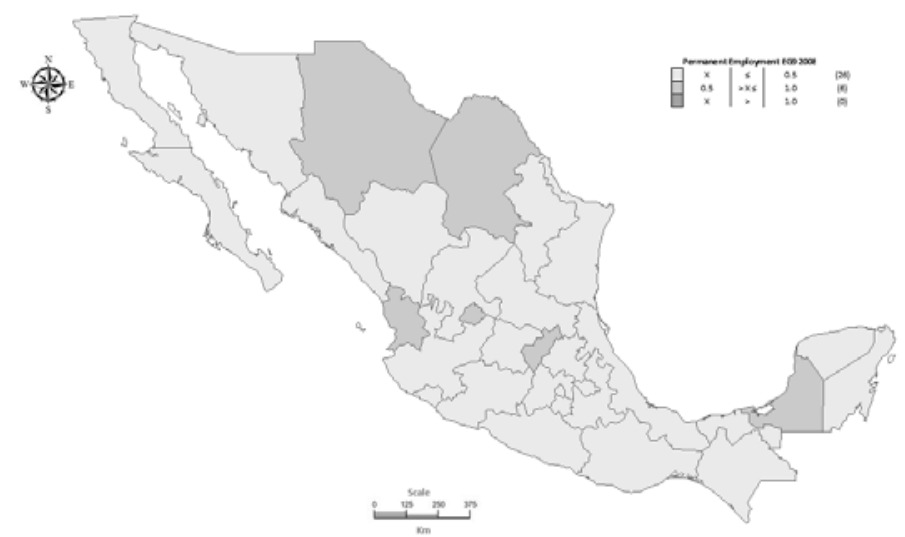

Source: own elaboration with information of the IMSS.

(c) Southern Regional Science Association 2017. 
Map 5: Temporary Employment Average Growth Rate over the First 9 Months of Expansions (EG9TEM1), 2001

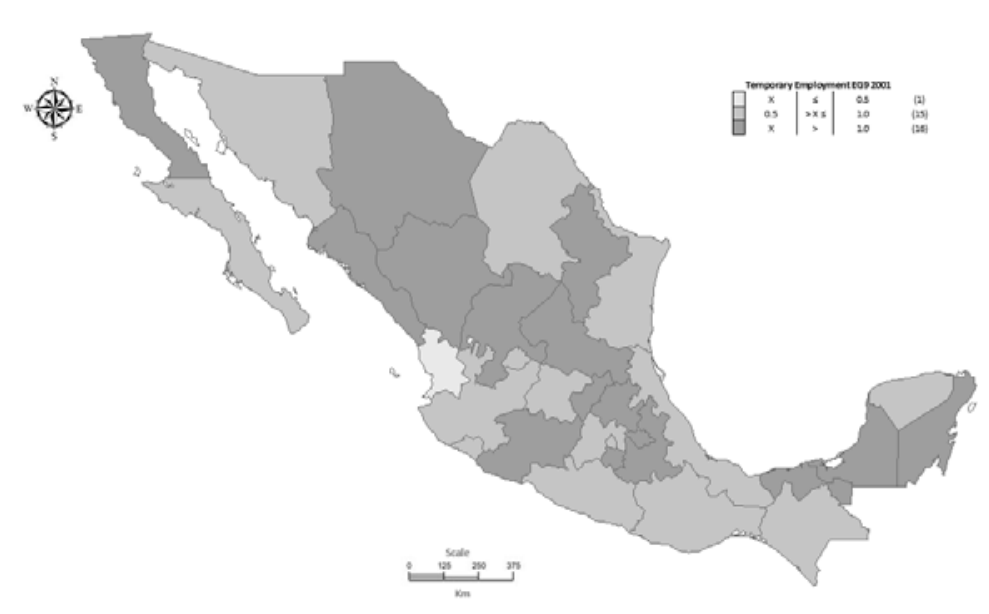

Source: own elaboration with information of the IMSS.
Map 6: Temporary Employment Average Growth Rate over the First 9 Months of Expansions (EG9TEM8), 2008

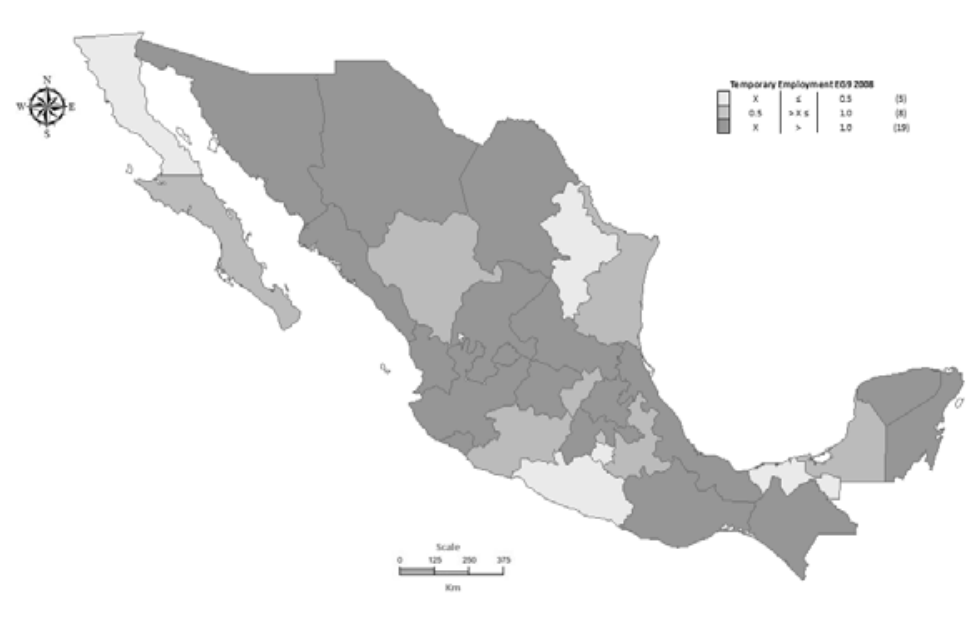

Source: own elaboration with information of the IMSS. 
recession. Of course, these results could be due to the effect of the control variables included in the models. Particularly, external and fiscal shocks seem to have played differentiated roles in each episode.

The estimates reported in the Tables 4-6 show that the growth rates of the tradable goods sector, which measures the degree of openness of the state economies and depends mainly on the external demand, played a significant role in the early expansion of permanent and total employment only after the 2008 recession. In opposition to what happened in the aftermath of the 2001 recession, these effects may be explained by the fact that the recuperation of economic activity in the U.S. and Mexican economies was highly synchronized, implying that the initial increase in the former's demand may have had a significant “pull” on the Mexican state economies.

On the other hand, given that fiscal shocks are measured by the growth rate of the federal government expenditure in the states during the trough year, the positive sign of the estimates suggests that public expenditure was cut when permanent employment was still falling. Of course, this pro-cyclical policy did not contribute to its recuperation, but it was in line with the policy followed in Mexico over the previous two decades.

In contrast, the estimated coefficients indicate that the federal government expenditure increased during the last year of the 2008 recession (Villagómez and Navarro, 2010), contributing to push permanent and total employment out over the downturn. Notice that public expenditures had no effects on the generation of temporary jobs.

Additionally, the response of state employment to recession characteristics may have also been conditioned in some sense by structural factors, as suggested by the literature on resilience. As mentioned above, these factors are measured as the average of the previous five years to the beginning of the state recessions in order to have indicators of the long lasting characteristics of the states. The positive and statistically significant effect of the growth rate of GDP per capita on the early expansion of employment after the 2001 recession, regardless of the type of employment, is a robust result suggesting that states with greater growth capacity experienced a greater "bounceback" effect. Moreover, the estimates reveal that, in general, its effects remain over the first 9 and 12 months of the subsequent expansions, but in the case of permanent employment they extend over the recovery phase as well. In contrast, during the post-2008 expansion the GDP per capita growth rate had effects only at the longer time horizon associated with the state recoveries of temporary employment.

Other structural factors had less systematic effects. For example, the ratio of secondary to tertiary production had positive and significant effects on the growth rate of permanent employment in the aftermath of the 2008 recession: the estimates suggest that states with a greater proportion of industrial production grew faster, which may be associated with the role that external shocks played in that episode. On the contrary, and only in the case of the average growth rate of temporary employment observed after the 2001 recession, the same ratio had negative effects disclosing the absence of external demand as a determining factor of its "bounce-back" effect.

The rest of the structural factors had non-robust effects on the early expansions of state employment: the estimated coefficients of the net migration rate, the distance from the state capital to the nearest important U.S. city, and the location at the U.S. border were statistically significant only in a few cases, without any recognizable pattern indicating systematic effects.

(C) Southern Regional Science Association 2017. ISSN 1553-0892, 0048-749X (online)

wWw.srsa.org/rrs 
Table 4: Effects of Recession Characteristics on Permanent Employment Growth Rates over Early Expansions in the Mexican States

\begin{tabular}{|c|c|c|c|c|c|c|}
\hline \multicolumn{7}{|c|}{ MODEL A } \\
\hline & \multicolumn{3}{|c|}{2001} & \multicolumn{3}{|c|}{2008} \\
\hline & EG9 & EG12 & EGR & EG9 & EG12 & EGR \\
\hline \multirow[t]{2}{*}{ Intercept } & 0.181 & 0.215 & 0.252 & 0.339 & 0.279 & 0.188 \\
\hline & $(0.102)$ & $(0.081)$ & $(0.008)$ & $(0.188)$ & $(0.218)$ & $(0.712)$ \\
\hline \multirow[t]{2}{*}{ Duration } & -0.004 & -0.003 & 0.001 & 0.001 & -0.004 & -0.003 \\
\hline & $(0.028)$ & $(0.124)$ & $(0.708)$ & $(0.738)$ & $(0.349)$ & $(0.791)$ \\
\hline \multirow[t]{2}{*}{ Depth } & -0.025 & -0.018 & 0.012 & 0.000 & -0.018 & 0.005 \\
\hline & $(0.001)$ & $(0.023)$ & $(0.198)$ & $(0.981)$ & $(0.143)$ & $(0.868)$ \\
\hline \multirow[t]{2}{*}{ Tradable goods growth } & -0.022 & -0.016 & -0.008 & 0.010 & 0.012 & 0.003 \\
\hline & $(0.002)$ & $(0.031)$ & $(0.295)$ & $(0.009)$ & $(0.001)$ & $(0.641)$ \\
\hline \multirow[t]{2}{*}{ Federal gov't growth } & 0.013 & 0.013 & 0.008 & -0.012 & -0.012 & -0.010 \\
\hline & $(0.009)$ & $(0.014)$ & $(0.116)$ & $(0.073)$ & $(0.047)$ & $(0.429)$ \\
\hline \multirow[t]{2}{*}{ Net migration } & 0.081 & 0.067 & 0.116 & -0.007 & -0.031 & 0.074 \\
\hline & $(0.015)$ & $(0.059)$ & $(0.000)$ & $(0.872)$ & $(0.465)$ & $(0.441)$ \\
\hline \multirow[t]{2}{*}{ GDP per capita growth } & 0.007 & 0.009 & 0.006 & -0.006 & -0.005 & -0.023 \\
\hline & $(0.010)$ & $(0.003)$ & $(0.013)$ & $(0.719)$ & $(0.703)$ & $(0.454)$ \\
\hline \multirow[t]{2}{*}{ Industry/Services ratio } & -0.001 & -0.001 & -0.001 & 0.001 & 0.001 & 0.002 \\
\hline & $(0.195)$ & $(0.311)$ & $(0.003)$ & $(0.003)$ & $(0.001)$ & $(0.001)$ \\
\hline \multirow[t]{2}{*}{ Distance to US cities (km) } & 0.000 & 0.000 & 0.000 & 0.000 & 0.000 & 0.000 \\
\hline & $(0.598)$ & $(0.992)$ & $(0.378)$ & $(0.158)$ & $(0.212$ & $(0.385)$ \\
\hline \multirow[t]{2}{*}{ Border (dummy) } & -0.035 & -0.045 & 0.021 & 0.028 & -0.041 & -0.075 \\
\hline & $(0.653)$ & $(0.597)$ & $(0.750)$ & $(0.793)$ & $(0.656)$ & $(0.724)$ \\
\hline $\bar{R}^{2}$ & 0.715 & 0.602 & 0.562 & 0.621 & 0.711 & 0.488 \\
\hline Jarque-Bera & 0.665 & 0.577 & 0.960 & 0.167 & 0.014 & 0.000 \\
\hline Breusch-Pagan test & 0.206 & 0.132 & 0.086 & 0.169 & 0.318 & 0.660 \\
\hline \multicolumn{7}{|c|}{ MODEL B } \\
\hline & \multicolumn{3}{|c|}{2001} & \multicolumn{3}{|c|}{2008} \\
\hline \multirow{3}{*}{ Intercept } & EG9 & EG12 & EGR & EG9 & EG12 & EGR \\
\hline & 0.221 & 0.252 & 0.195 & 0.304 & 0.283 & -0.161 \\
\hline & $(0.059)$ & $(0.010)$ & $(0.102)$ & $(0.224)$ & $(0.223)$ & $(0.610)$ \\
\hline \multirow[t]{2}{*}{ Steepness } & -0.141 & -0.023 & 0.037 & -0.116 & -0.109 & -0.439 \\
\hline & $(0.031)$ & $(0.784)$ & $(0.565)$ & $(0.365)$ & (0.359) & $(0.012)$ \\
\hline \multirow[t]{2}{*}{ Tradable goods growth } & -0.022 & -0.015 & -0.008 & 0.009 & 0.011 & 0.009 \\
\hline & $(0.005)$ & $(0.085)$ & $(0.260)$ & $(0.010)$ & $(0.001)$ & $(0.041)$ \\
\hline \multirow[t]{2}{*}{ Federal gov't growth } & 0.012 & 0.011 & 0.007 & -0.013 & -0.012 & 0.005 \\
\hline & $(0.018)$ & $(0.094)$ & $(0.159)$ & $(0.049)$ & $(0.052)$ & $(0.561)$ \\
\hline \multirow[t]{2}{*}{ Net migration } & 0.047 & 0.078 & 0.117 & -0.019 & -0.012 & -0.072 \\
\hline & $(0.293)$ & $(0.218)$ & $(0.015)$ & $(0.667)$ & $(0.764)$ & $(0.210)$ \\
\hline GDP per capita growth & 0.008 & 0.009 & 0.006 & -0.008 & -0.005 & -0.014 \\
\hline & $(0.009)$ & $(0.010)$ & $(0.072)$ & $(0.579)$ & $(0.692)$ & $(0.424)$ \\
\hline Industry/Services ratio & -0.001 & -0.001 & -0.001 & 0.001 & 0.001 & 0.002 \\
\hline & $(0.365)$ & $(0.072)$ & $(0.085)$ & $(0.002)$ & $(0.001)$ & $(0.000)$ \\
\hline Distance to US cities (km) & 0.000 & 0.000 & 0.000 & 0.000 & 0.000 & 0.000 \\
\hline & $(0.798)$ & $(0.764)$ & $(0.320)$ & $(0.125)$ & $(0.148)$ & $(0.964)$ \\
\hline Border (dummy) & 0.006 & -0.022 & 0.002 & -0.008 & 0.006 & -0.172 \\
\hline & $(0.945)$ & $(0.756)$ & $(0.979)$ & $(0.927)$ & $(0.946)$ & $(0.144)$ \\
\hline $\bar{R}^{2}$ & 0.621 & 0.497 & 0.499 & 0.627 & 0.686 & 0.808 \\
\hline Jarque-Bera & 0.665 & 0.497 & 0.138 & 0.183 & 0.192 & 0.001 \\
\hline Breusch-Pagan test & 0.577 & 0.132 & 0.842 & 0.119 & 0.395 & 0.270 \\
\hline
\end{tabular}


Table 5: Effects of Recession Characteristics on Temporary Employment Growth Rates over Early Expansions in the Mexican States

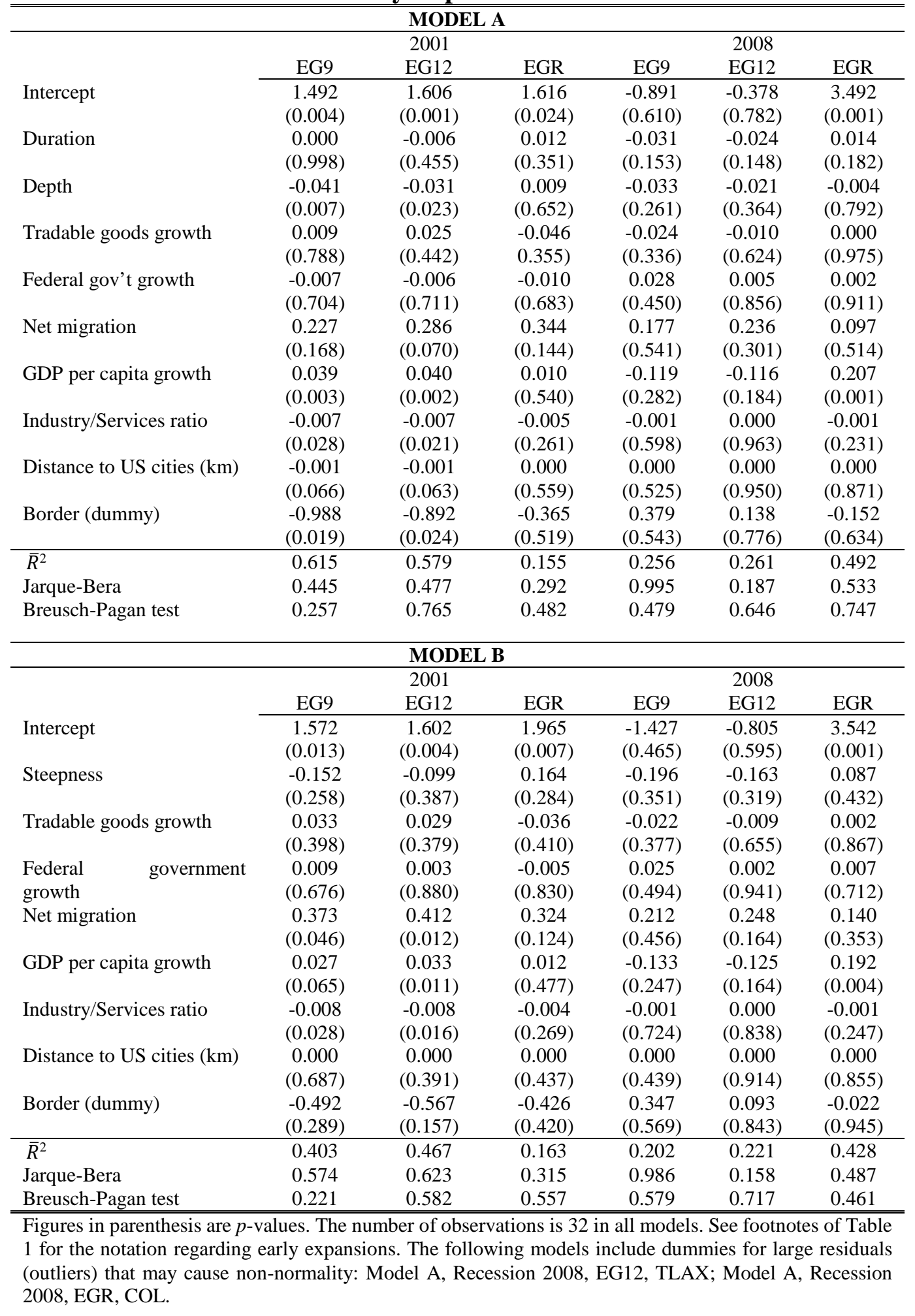


Table 6: Effects of Recession Characteristics on Total Employment Growth Rates over Early Expansions in the Mexican States

\begin{tabular}{|c|c|c|c|c|c|c|}
\hline \multicolumn{7}{|c|}{ MODEL A } \\
\hline & \multicolumn{3}{|c|}{2001} & \multicolumn{3}{|c|}{2008} \\
\hline & EG9 & EG12 & EGR & EG9 & EG12 & EGR \\
\hline \multirow[t]{2}{*}{ Intercept } & 0.251 & 0.362 & 0.438 & 0.193 & 0.248 & 0.717 \\
\hline & $(0.177)$ & $(0.013)$ & $(0.032)$ & $(0.585)$ & $(0.454)$ & $(0.105)$ \\
\hline \multirow[t]{2}{*}{ Duration } & 0.000 & -0.001 & -0.005 & 0.003 & 0.002 & -0.002 \\
\hline & $(0.930)$ & $(0.861)$ & $(0.216)$ & $(0.529)$ & $(0.562)$ & $(0.762)$ \\
\hline \multirow[t]{2}{*}{ Depth } & -0.023 & -0.022 & -0.005 & -0.023 & -0.016 & -0.014 \\
\hline & $(0.054)$ & $(0.019)$ & $(0.689)$ & $(0.175)$ & $(0.317)$ & $(0.497)$ \\
\hline \multirow[t]{2}{*}{ Tradable goods growth } & -0.006 & -0.017 & -0.009 & 0.013 & 0.013 & 0.007 \\
\hline & $(0.594)$ & $(0.057)$ & $(0.479)$ & $(0.005)$ & $(0.002)$ & $(0.180)$ \\
\hline \multirow[t]{2}{*}{ Federal gov't growth } & -0.006 & -0.006 & 0.005 & -0.019 & -0.017 & -0.016 \\
\hline & $(0.414)$ & $(0.280)$ & $(0.550)$ & $(0.021)$ & $(0.026)$ & $(0.096)$ \\
\hline \multirow[t]{2}{*}{ Net migration } & 0.067 & 0.098 & 0.074 & -0.031 & -0.029 & -0.033 \\
\hline & $(0.177)$ & $(0.012)$ & $(0.173)$ & $(0.692)$ & $(0.686)$ & $(0.727)$ \\
\hline \multirow[t]{2}{*}{ GDP per capita growth } & 0.014 & 0.022 & 0.010 & -0.011 & -0.011 & 0.014 \\
\hline & $(0.001)$ & $(0.000)$ & $(0.036)$ & $(0.577)$ & $(0.581)$ & $(0.583)$ \\
\hline \multirow[t]{2}{*}{ Industry/Services ratio } & 0.000 & -0.002 & -0.001 & 0.000 & 0.000 & 0.000 \\
\hline & $(0.635)$ & $(0.018)$ & $(0.320)$ & $(0.223)$ & $(0.132)$ & $(0.690)$ \\
\hline \multirow[t]{2}{*}{ Distance to US cities (km) } & $0.000)$ & 0.000 & 0.000 & 0.000 & 0.000 & 0.000 \\
\hline & $(0.766)$ & $(0.442)$ & $(0.620)$ & $(0.515)$ & $(0.396)$ & $(0.438)$ \\
\hline \multirow[t]{2}{*}{ Border (dummy) } & -0.167 & -0.187 & -0.055 & -0.093 & -0.062 & -0.116 \\
\hline & $(0.200)$ & $(0.058)$ & $(0.683)$ & $(0.464)$ & $(0.601)$ & $(0.454)$ \\
\hline $\bar{R}^{2}$ & 0.822 & 0.889 & 0.576 & 0.555 & 0.557 & 0.263 \\
\hline Jarque-Bera & 0.370 & 0.553 & 0.330 & 0.848 & 0.922 & 0.434 \\
\hline Breusch-Pagan test & 0.780 & 0.814 & 0.862 & 0.177 & 0.384 & 0.297 \\
\hline \multicolumn{7}{|c|}{ MODEL B } \\
\hline & \multicolumn{3}{|c|}{2001} & \multicolumn{3}{|c|}{2008} \\
\hline \multirow{3}{*}{ Intercept } & EG9 & EG12 & EGR & EG9 & EG12 & EGR \\
\hline & 0.405 & 0.481 & 0.321 & 0.235 & 0.312 & 0.705 \\
\hline & $(0.018)$ & $(0.001)$ & $(0.061)$ & $(0.556)$ & $(0.380)$ & $(0.088)$ \\
\hline \multirow[t]{2}{*}{ Steepness } & -0.274 & -0.177 & -0.162 & -0.125 & 0.012 & -0.215 \\
\hline & $(0.055)$ & $(0.120)$ & $(0.278)$ & $(0.454)$ & $(0.935)$ & $(0.207)$ \\
\hline \multirow[t]{2}{*}{ Tradable goods growth } & -0.006 & -0.016 & -0.006 & 0.011 & 0.012 & 0.006 \\
\hline & $(0.617)$ & $(0.093)$ & $(0.648)$ & $(0.032)$ & $(0.009)$ & $(0.238)$ \\
\hline \multirow[t]{2}{*}{ Federal gov't growth } & -0.001 & -0.002 & -0.002 & -0.014 & -0.013 & -0.014 \\
\hline & $(0.813)$ & $(0.691)$ & $(0.714)$ & $(0.108)$ & $(0.083)$ & $(0.114)$ \\
\hline \multirow[t]{2}{*}{ Net migration } & 0.005 & 0.064 & 0.034 & 0.021 & 0.028 & -0.033 \\
\hline & $(0.935)$ & $(0.223)$ & $(0.616)$ & $(0.768)$ & $(0.658)$ & $(0.640)$ \\
\hline GDP per capita growth & 0.015 & 0.022 & 0.011 & -0.020 & -0.016 & 0.012 \\
\hline & $(0.001)$ & $(0.000)$ & $(0.013)$ & $(0.390)$ & $(0.441)$ & $(0.601)$ \\
\hline Industry/Services ratio & 0.000 & -0.002 & -0.001 & 0.000 & 0.000 & 0.000 \\
\hline & $(0.753)$ & $(0.035)$ & $(0.581)$ & $(0.243)$ & $(0.130)$ & $(0.729)$ \\
\hline Distance to US cities (km) & 0.000 & 0.000 & 0.000 & 0.000 & 0.000 & 0.000 \\
\hline & $(0.174)$ & $(0.114)$ & $(0.612)$ & $(0.256)$ & $(0.264)$ & $(0.231)$ \\
\hline Border (dummy) & -0.129 & -0.148 & -0.044 & -0.053 & 0.001 & -0.144 \\
\hline & $(0.315)$ & $(0.154)$ & $(0.738)$ & $(0.709)$ & $(0.991)$ & $(0.318)$ \\
\hline $\bar{R}^{2}$ & 0.804 & 0.858 & 0.565 & 0.377 & 0.438 & 0.294 \\
\hline Jarque-Bera & 0.301 & 0.386 & 0.393 & 0.617 & 0.338 & 0.316 \\
\hline Breusch-Pagan test & 0.635 & 0.224 & 0.937 & 0.608 & 0.817 & 0.319 \\
\hline
\end{tabular}




\section{CONCLUSIONS}

This paper has tested the "bounce-back" effect hypothesis of Friedman $(1969,1993)$ and other theoretical models for the case of the Mexican states. The basic idea is that deeper, steeper, and/or longer recessions are followed by stronger early expansions due to a self-corrective response of the system to low economic activity. We have analyzed the effects of prior recessions on subsequent early expansions of total, permanent, and temporary employment of the Mexican states using the models proposed by Wynne and Balke (1992) and Balke and Wynne (1995). These models have been extended to take into account the effects of external and fiscal shocks as well as the role of structural characteristics of the states. The effects of the two most recent international recessions (2001 and 2008-2009) are analyzed.

State recessions and expansions are dated using a classical business cycles approach, which allows us to characterize the former in terms of their steepness, depth, and duration and to measure employment growth over the first 9 and 12 months as well as over the duration of the (classical) recovery. Two econometric model specifications have been estimated for each type of employment including depth and duration (Model A) and steepness (Models B) as explanatory variables plus the same set of control variables. Some models have been corrected to overcome specification problems.

After controlling for the effects of other shocks and structural characteristics, we find a negative robust relationship between recession depth and steepness and growth over the early expansions (up to 12 months) that followed the 2001 recession, regardless of the type of employment. In this episode, the initial impulse that could have come from external demand was absent in all models, while federal government expenditures do not seem to have contributed to push permanent employment out over the slump as it decreased when state employment was still falling. Such a type of result is in line with the pro-cyclical fiscal policy that the Mexican authorities had followed during the previous two decades. Moreover, fiscal impulses had no role in the recovery of temporal and total employment. Regarding structural factors, the evidence suggests that the growth capacity of the state economies, measured by the growth rate of GDP per capita, played a significant role in the recovery of employment, a dynamic that may be linked to the concept of resilience. Therefore, there is some support to the "bounce-back" effect, the "plucking," and other models in this episode.

In contrast, state employment growth in the aftermath of the 2008 recession does not seem to have responded to the characteristics of prior recessions, contrary to what was expected given the severity of that cycle phase. Based on the econometric estimations, it could be argued that employment growth was determined mainly by the recuperation of external demand as demonstrated by two facts. First, the positive and significant effects of the growth rate of the tradable goods sector, largely determined by the highly synchronized revivals in economic activity of Mexico and the U.S. Second, the positive and significant effects of the ratio of industrial to services production suggest that employment grew faster in states more associated with external demand of manufactures and minerals (mainly oil). Furthermore, the increase of federal government expenditure in the onset of the state expansions provided additional impulse to the upturn, implying that the counter-cyclical policy followed by the government had some effectiveness. In general, the evidence reported in this paper provides support to the "bounce-back" effect in the case of the Mexican states employment, especially when other shocks or structural factors play a minor role. 
Although our paper analyzes a very specific relationship, as far as we know, it is the first one that addresses the interaction between the business cycle regimes of the Mexican states. More importantly, it opens a sensible research agenda that could be associated with the study of the medium and long run effects of recessions, more in line with the literature of resilience, a phenomenon that has been scarcely studied not only in Mexico but also in other developing countries.

\section{REFERENCES}

Abiad, Abdul, Ravi Balakrishnan, Petya Koeva Brooks, Daniel Leigh, and Irina Tytell. (2009) "What's the Damage? Medium-term Output Dynamics after Banking Crises," IMF Working Paper 09/245.

Aghion, Philippe and Gilles Saint-Paul. (1991) "On the Virtue of Bad Times: An Analysis of the Interaction between Economic Fluctuations and Productivity Growth,” CEPR Discussion Paper 578: London.

Antón, Arturo S. (2011) "Efectos del Ciclo Económico en Estados Unidos sobre la Producción y el Empleo en México,” in P. Mejía and M. E. Morales (eds.), Integración y Recesión Económica en el Binomio México-Estados Unidos, Universidad Autónoma del Estado de México: Toluca, México.

Artis, Michael J., Zenon G. Kontolemis, and Denise R. Osborn. (1997) “Business Cycles for G7 and European Countries,” The Journal of Business, 70, 1-16.

Aspe, Pedro. (1993) Economic Transformation the Mexican Way. MIT Press: Cambridge, Massachusetts.

Auerbach, Alan J. and Yuriy Gorodnichenko. (2010) "Measuring the Output Responses to Fiscal Policy,” NBER Working Paper 163112.

Balke, Nathan S. and Mark A. Wynne. (1994) “The Dynamics of Recoveries,” Federal Reserve Bank of Dallas Working Paper 94/06.

Balke, Nathan S. and Mark A. Wynne. (1995) "Recessions and Recoveries in Real Business Cycle Models,” Economic Inquiry, 33, 640-663.

Balke, Nathan S. and Mark A. Wynne. (1996) "Are Deeper Recessions Followed by Stronger Recoveries? Results for the G-7 Countries,” Applied Economics, 28, 889 -897.

Baxter, Marianne and Michael A. Kouparitsas. (2005) "Determinants of Business Cycle Comovement: A Robust Analysis,” Journal of Monetary Economics, 52, 113-157.

Blanchard, Oliver. (2009) “The Crisis: Basic Mechanisms and Appropriate Policies,” IMF Working Paper 09/80.

Boldin, Michael D. (1994) “Dating Turning Points in the Business Cycle," The Journal of Business, 67, 97-131.

Bordo, Michael D. and Joseph G. Haubrich. (2012) “Deep Recessions, Fast Recoveries, and Financial Crisis: Evidence from the American Record," Federal Reserve Bank of Cleveland Working Paper 18194.

Burns, Arthur F. and Wesley C. Mitchell. (1946) Measuring Business Cycles. Studies in Business Cycles, National Bureau of Economic Research, No. 2: New York.

(c) Southern Regional Science Association 2017. 
Caballero, Ricardo J. and Mohamad L. Hammour. (1994) “The Cleansing Effect of Recessions,” American Economic Review, 84, 1350-1368.

Cerra, Valerie, Ugo Panizza, and Sweta C. Saxena. (2013) "International Evidence on Recovery from Recessions," Contemporary Economic Policy, 31, 424-439.

Delajara, Marcelo. (2013) "Comovimiento y Concordancia Cíclica del Empleo en los Estados Mexicanos,” Economía Mexicana. Nueva Época, 22, 297-340.

Dominguez, Kathryn. M. and Matthew D. Shapiro. (2013) "Forecasting the Recovery from the Great Recession: Is this Time Different?” NBER Working Paper 18751.

Elwell, Craig K. (2013) "Economic Recovery: Sustaining U.S. Economic Growth in a Post-crisis Economy.” Congressional Research Service.

Erquizio, Alfredo E. (2006) Ciclos Económicos en México. Universidad de Sonora: Hermosillo, México.

Erquizio, Alfredo E. (2008) "Ciclos Económicos del Estado de México en el Contexto Regional: 1980-2005.” in P. Mejía, L. E. Del Moral, and O. M. Rodríguez (eds.), Actividad Económica en el Estado de México: Desempeño Productivo y Sector Externo. Government of Mexico: Toluca, México.

Erquizio, Alfredo E. (2011) "La Gran Recesión de Estados Unidos y de México 2008-2009 y sus Efectos Regionales," in P. Mejía-Reyes and M. E. Morales-Fajardo (eds.), Integración y Recesión Económica en el Binomio México-Estados Unidos, UAEMex: Toluca, México.

Erquizio, Alfredo E. and Roberto Ramírez. (2014) "La Recesión de 2009 y la Expansión 20102012 en las Entidades Federativas de México,” Estudios Fronterizos, 15, 181-213.

Fatás, Antonio and Ilián Mihov. (2000) "Fiscal Policy and Business Cycles: An Empirical Investigation,” INSEAD and CEPR Working Paper.

Friedman, Milton. (1969) The Optimum Quantity of Money and Other Essays. Aldine Publishing Company: Chicago.

Friedman, Milton. (1993) “The "Plucking Model” of Business Fluctuations Revisited,” Economic Inquiry, 31, 171-177.

Grossmann-Wirth, Vincent and Sophie Rivaud. (2010) "The Employment Content of Growth in the Current Recovery in the US," Economie \& Prevision, 4, 165-171.

Gutiérrez, Elías E., Pablo Mejía, and Benjamín Cruz. (2005) “Ciclos Económicos y Sector Externo en México. Evidencia de Relaciones Cambiantes en el Tiempo,” Estudios Económicos de Desarrollo Internacional. 5, 65-92.

Hansen, Alvin. (1965) “La Contribución de Schumpeter a la Teoría del Ciclo Económico,” in S. E. Harris (ed.), Schumpeter, Científico Social. Oikos-Tau: Barcelona, España, pp.169-175.

Imbs, Jean. (2009) “The First Global Recession in Decades," HEC Lausanne, Swiss Finance Institute, and CEPR Manuscript.

Kannan, Prakash, Alasdair Scott, and Marco E. Terrones. (2014) "From Recession to Recovery: How Soon and How Strong,” Financial Crises: Causes, Consequences, and Policy Responses, 239-274. 
King, Robert G., Charles I. Plosser, and Sergio T. Rebelo. (1988) "Production, Growth and Business Cycles: I. The Basic Neoclassical Model,” Journal of Monetary Economics, 21, 195-232.

Kliesen, Kevin L. (2003) “The 2001 Recession: How Was it Different and What Developments May Have Caused It?” The Federal Reserve Bank of St. Louis Review, 85, 23-38.

Kose, M. Ayhan and Kei-Mu Yi. (2001) "International Trade and Business Cycles: Is Vertical Specialization the Missing Link?” American Economic Review, 91, 371-375.

Kose, M. Ayhan, Guy M. Meredith, and Christopher M. Towe. (2004) "How Has NAFTA Affected the Mexican Economy? Review and Evidence,” IMF Working Paper 04/59.

Kydland, Finn E. and Edward C. Prescott. (1990) "Business Cycles: Real Facts and a Monetary Myth,” Federal Reserve Bank of Minneapolis Quarterly Review, 14, 3-18.

Lavender, Brady and Nicolas Parent. (2013) “The U.S. Recovery from the Great Recession: A Story of Debt and Deleveraging,” Bank of Canada Review, Winter 2012-2013, 13-26.

Lucas, Robert E. (1977) “Understanding Business Cycles,” Carnegie-Rochester Conference Series in Public Policy, 5, 7-29.

Martin, Ron. (2012) "Regional Economic Resilience, Hysteresis and Recessionary Shocks,” Journal of Economic Geography, 12, 1-32.

Mejía, Pablo. (1999) "Classical Business Cycles in Latin America: Turning Points, Asymmetries and International Synchronization,” Estudios Económicos, 14, 265-297.

Mejía, Pablo. (2003) "Regularidades Empíricas en los Ciclos Económicos de México: Producción, Inversión, Inflación y Balanza Comercial,” Economía Mexicana. Nueva Época, 12, 231274.

Mejía, Pablo. (2004) "Classical Business Cycles in America: Are National Business Cycles Synchronised?” International Journal of Applied Econometrics and Quantitative Studies, 1, 75-102.

Mejía, Pablo. (2007) "Expansions and Recessions in the Mexican States: A Classical Business Cycles Approach,” Panorama Económico, 3, 7-38.

Mejía, Pablo and Jeanett Campos. (2011) “Are the Mexican States and the United States Business Cycles Synchronised? Evidence from the Manufacturing Production," Economía Mexicana. Nueva Época 20, 79-112.

Mejía, Pablo and Alfredo E. Erquizio. (2012) Expansiones y Recesiones en los Estados de México. UNISON-Pearson-UAEM: Hermosillo, México.

Mitchell, Wesley C. (1927) Business Cycles: The Problems and its Setting. NBER: New York.

Miyazaki, Tomomi. (2013) "Fiscal Policy and Regional Business Cycle Fluctuations in Japan,” Institute of Economic Research, Hitotsubashi University, Discussion Paper Series A 583.

Moore, Geoffrey H. (1965) “Tested Knowledge of Business Cycles,” in R. A. Gordon and L. R. Klein (eds), Readings in Business Cycles. American Economic Association: Nashville. 
Moore, Geoffrey H. and Victor Zarnowitz. (1986) "The Development and Role of the National Bureau of Economic Research's Business Cycle Chronologies,” in Gordon, R. J. (ed.), The American Business Cycles. Chicago University Press: Chicago, pp. 735-779.

Moreno-Brid, Juan Carlos and Jaime Ros. (2009) Development and Growth in the Mexican Economy. Oxford University Press: New York.

Nordhaus, William N. (2002) “The Recent Recession, the Current Recovery, and Stock Prices," Brookings Papers on Economic Activity, 2002, 199-220.

Ramírez, Ramon de Jesús and Ramón A. Castillo. (2009) "Integración Económica en América del Norte: Lección de la Experiencia de la Unión Europea para el TLCAN,” Estudios Fronterizos, 10, 183-208.

Rickman, Dan and Mouhcine Guettabi. (2015) "The Great Recession and Nonmetropolitan America,” Journal of Regional Science, 55, 93-112.

Rodden, Jonathan and Erik Wibbels. (2010) "Fiscal Decentralization and the Business Cycle: An Empirical Study of Seven Federations,” Economics \& Politics, 22, 37-67.

Schumpeter, Joseph A. (1939) Business cycles: A Theoretical, Historical and Statistical Analysis of the Capitalist Process. McGraw-Hill: New York.

Souvik, Gupta and Miniane Jacques. (2009) "Recessions and Recoveries in Asia: What Can the Past Teach Us About the Present Recession?” Asian Development Bank Institute Working Paper 150.

Sosa, Sebastian. (2008) "External Shocks and Business Cycle Fluctuations in Mexico: How Important are U.S. Factors?” International Monetary Fund Working Paper 08/100.

Tichy, Ondrej. (2011) “Schumpeterian Business Cycles: Past, Present and Future,” Economics and Management, 16, 1068-1074.

Tornell, Aaron, Frank Westermann, and Lorenza Martínez Trigueros. (2004) "NAFTA and Mexico’s Economic Performance,” CESifo Working Paper 1155.

UKCES. (2014) “The Labour Market History: The UK Following Recession,” Briefing Paper. UK Commission for Employment and Skills.

Villagómez, Alejandro and Luis Navarro. (2010) "Política Fiscal Contracíclica en México durante la Crisis Reciente: Un Análisis Preliminar," Centro de Investigación y Docencia Económicas Working Paper 475.

Wynne, Mark A. and Nathan S. Balke. (1992) “Are Deep Recessions Followed by Strong Recoveries?” Economics Letters, 39, 183-189.

Wynne, Mark., A. and Nathan. S. Balke. (1993) "Recessions and Recoveries," Economic Review (Federal Reserve Bank of Dallas), First Quarter 1993, 1-18. 
APPENDIX 1: Classical Business Cycles Chronology and Regime Characteristics of Employment in the Mexican States Total Employment

\begin{tabular}{|c|c|c|c|c|c|c|c|c|c|c|c|c|c|c|c|c|c|c|}
\hline \multirow[b]{3}{*}{ States } & \multicolumn{9}{|c|}{2001} & \multicolumn{9}{|c|}{2008} \\
\hline & \multirow[b]{2}{*}{ Peak } & \multirow[b]{2}{*}{ Trough } & \multirow[b]{2}{*}{ Duration } & \multirow[b]{2}{*}{ Depth } & \multirow[b]{2}{*}{ Steepness } & \multicolumn{4}{|c|}{ Early expansion* } & \multirow[b]{2}{*}{ Peak } & \multirow{3}{*}{$\frac{\text { Trough }}{2009 / 05}$} & \multirow{3}{*}{ Duration } & \multirow{3}{*}{$\frac{\text { Depth }}{-4208}$} & \multirow{3}{*}{$\begin{array}{c}\text { Steepness } \\
-0.429\end{array}$} & \multicolumn{4}{|c|}{ Early expansion * } \\
\hline & & & & & & EG9 & EG12 & & $(* *)$ & & & & & & EG9 & EG12 & EGR ( & $(* *)$ \\
\hline $\mathrm{NAT}^{+}$ & $2000 / 11$ & $2003 / 08$ & 32 & -3.149 & -0.100 & 0.247 & 0.247 & 0.291 & $(4)$ & $2008 / 07$ & & & & & 0.273 & 0.333 & 0.334 & $(13)$ \\
\hline AGS & 2001/02 & $2002 / 03$ & 13 & -4.676 & -0.368 & 1.670 & 1.307 & 0.171 & (35) & $2007 / 11$ & 2009/06 & 19 & -7.020 & -0.382 & 0.511 & 0.436 & 0.319 & (24) \\
\hline $\mathrm{BC}$ & $2000 / 11$ & $2003 / 05$ & 30 & -9.092 & -0.317 & 0.339 & 0.440 & 0.400 & (24) & 2008/01 & $2009 / 06$ & 17 & 11.764 & -0.734 & 0.427 & 0.349 & 0.316 & (40) \\
\hline BCS & $2001 / 08$ & 2002/03 & 7 & -4.677 & -0.682 & 0.220 & 0.136 & 0.283 & (22) & 2008/05 & $2009 / 10$ & 17 & 14.442 & -0.913 & 0.214 & 0.138 & 0.254 & (39) \\
\hline CAM & 1999/08 & $2000 / 04$ & 8 & -3.167 & -0.401 & 1.004 & 1.078 & 0.854 & (4) & 2009/06 & 2010/01 & 7 & -4.678 & -0.682 & 0.413 & 0.444 & 0.455 & (11) \\
\hline CHIS & 2000/09 & 2001/02 & 5 & -3.082 & -0.624 & 0.151 & 0.186 & 0.213 & (15) & 2006/09 & 2006/12 & 3 & -1.622 & -0.544 & 0.173 & 0.151 & 0.227 & (8) \\
\hline CHIH & $2000 / 10$ & 2003/05 & 31 & -15.775 & -0.552 & 0.201 & 0.202 & 0.125 & (116) & 2007/08 & 2009/05 & 21 & 15.860 & -0.819 & 0.570 & 0.610 & 0.394 & (44) \\
\hline $\mathrm{COA}$ & $2000 / 11$ & 2003/08 & 33 & -8.807 & -0.279 & 0.301 & 0.230 & 0.233 & $(54)$ & 2008/06 & 2009/06 & 12 & 10.332 & -0.905 & 0.797 & 0.818 & 0.798 & (14) \\
\hline COL & $2002 / 04$ & 2003/03 & 11 & -2.852 & -0.263 & 0.423 & 0.389 & 0.602 & (6) & 2008/06 & $2009 / 05$ & 11 & -2.371 & -0.218 & 0.382 & 0.477 & 0.780 & (4) \\
\hline $\mathrm{DF}$ & $2000 / 08$ & 2003/08 & 36 & -2.798 & -0.079 & 0.196 & 0.176 & 0.177 & (17) & $2008 / 10$ & $2009 / 11$ & 13 & -3.746 & -0.293 & 0.313 & 0.352 & 0.352 & (12) \\
\hline DGO & $2000 / 10$ & 2003/08 & 34 & -13.224 & -0.416 & 0.510 & 0.449 & 0.170 & (87) & 2008/02 & $2009 / 07$ & 17 & -4.404 & -0.265 & 0.494 & 0.357 & 0.360 & (13) \\
\hline GTO & 2001/02 & 2001/09 & 7 & -0.769 & -0.110 & 0.114 & 0.186 & 0.262 & (3) & 2008/06 & $2009 / 05$ & 11 & -2.822 & -0.260 & 0.532 & 0.515 & 0.474 & (7) \\
\hline GRO & 2001/02 & $2002 / 04$ & 14 & -4.698 & -0.343 & 0.164 & 0.113 & 0.264 & (19) & $2008 / 07$ & $2012 / 02$ & 43 & -4.739 & -0.113 & 0.279 & 0.198 & 0.198 & (11) \\
\hline HGO & $2001 / 05$ & 2003/08 & 27 & -5.700 & -0.217 & 0.419 & 0.242 & 0.170 & (35) & $2008 / 10$ & $2009 / 09$ & 11 & -6.172 & -0.577 & 0.343 & 0.420 & 0.478 & (14) \\
\hline JAL & $2000 / 11$ & $2001 / 11$ & 12 & -2.435 & -0.205 & 0.131 & 0.150 & 0.112 & (26) & 2008/09 & $2009 / 05$ & 8 & -2.504 & -0.316 & 0.224 & 0.294 & 0.258 & (10) \\
\hline MEX & $2001 / 01$ & 2003/08 & 31 & -3.653 & -0.120 & 0.094 & 0.135 & 0.147 & (27) & 2008/09 & $2009 / 07$ & 10 & -4.246 & -0.433 & 0.450 & 0.442 & 0.464 & (10) \\
\hline MICH & & $2003 / 08^{+}$ & 0 & & & 0.182 & 0.147 & 0.147 & (12) & & $2009 / 05^{+}$ & 0 & & & 0.236 & 0.334 & 0.334 & (12) \\
\hline MOR & $2000 / 05$ & $2002 / 11$ & 30 & -2.619 & -0.088 & 0.197 & 0.191 & 0.207 & (16) & 2009/05 & $2010 / 03$ & 7 & -2.572 & -0.372 & 0.322 & 0.370 & 0.322 & (9) \\
\hline NAY & $2001 / 08$ & $2002 / 05$ & 16 & -6.107 & -0.393 & 0.413 & 0.791 & 0.709 & (11) & $2008 / 07$ & $2009 / 05$ & 10 & -6.302 & -0.649 & 0.609 & 0.530 & 0.530 & (13) \\
\hline NL & $2000 / 11$ & $2001 / 03$ & 16 & -2.897 & -0.184 & 0.223 & 0.197 & 0.120 & (26) & 2008/09 & $2009 / 05$ & 8 & -6.042 & -0.776 & 0.420 & 0.493 & 0.483 & (13) \\
\hline OAX & & $2003 / 08^{+}$ & 0 & & & 0.296 & 0.263 & 0.263 & (12) & & $2009 / 05^{+}$ & 0 & & & 0.085 & 0.187 & 0.187 & (12) \\
\hline PUE & $2000 / 10$ & $2004 / 02$ & 40 & -8.235 & -0.215 & 0.249 & 0.249 & 0.161 & (55) & 2008/09 & 2009/02 & 5 & -3.135 & -0.635 & 0.160 & 0.226 & 0.271 & (13) \\
\hline QRO & $2001 / 01$ & 2001/09 & 8 & -3.183 & -0.403 & 0.314 & 0.280 & 0.430 & (10) & 2008/09 & $2009 / 07$ & 10 & -5.356 & -0.549 & 0.904 & 0.869 & 0.889 & (7) \\
\hline QROO & $2001 / 08$ & $2001 / 11$ & 3 & -5.283 & -1.793 & 0.564 & 0.582 & 0.503 & (11) & 2008/09 & $2009 / 06$ & 9 & -8.476 & -0.979 & 0.503 & 0.418 & 0.300 & (30) \\
\hline SLP & $2002 / 07$ & $2003 / 11$ & 16 & -2.063 & -0.130 & 0.396 & 0.437 & 0.445 & (5) & $2008 / 05$ & $2009 / 10$ & 17 & -4.833 & -0.291 & 0.662 & 0.648 & 0.694 & (8) \\
\hline SIN & $2003 / 06$ & $2004 / 02$ & 8 & -1.965 & -0.248 & 0.505 & 0.404 & 1.005 & (2) & 2008/11 & 2009/06 & 7 & -3.986 & -0.579 & 0.482 & 0.360 & 0.596 & (7) \\
\hline SON & $2000 / 11$ & 2003/02 & 27 & -11.288 & -0.443 & 0.243 & 0.169 & 0.448 & (28) & 2008/01 & $2009 / 07$ & 18 & -8.053 & -0.465 & 0.694 & 0.651 & 0.584 & (15) \\
\hline $\mathrm{TAB}$ & $2000 / 11$ & $2001 / 07$ & 8 & -2.906 & -0.368 & 0.126 & 0.031 & 0.202 & (16) & 2008/12 & $2009 / 05$ & 5 & -1.617 & -0.326 & 0.281 & 0.320 & 0.514 & (4) \\
\hline TAM & $2000 / 11$ & $2003 / 08$ & 33 & -7.587 & -0.239 & 0.365 & 0.373 & 0.374 & (22) & $2008 / 04$ & $2009 / 07$ & 15 & -9.994 & -0.699 & 0.398 & 0.411 & 0.238 & (42) \\
\hline TLAX & $2000 / 11$ & $2004 / 02$ & 39 & -12.543 & -0.343 & 0.621 & 0.496 & 0.109 & (107) & $2005 / 01$ & 2009/08 & 55 & 14.861 & -0.292 & 0.828 & 0.822 & 0.527 & (31) \\
\hline VER & $2001 / 11$ & $2002 / 05$ & 6 & -3.090 & -0.522 & 0.410 & 0.125 & 0.410 & (8) & $2009 / 07$ & $2009 / 09$ & 2 & -1.881 & -0.945 & 0.540 & 0.436 & 0.718 & (3) \\
\hline YUC & & $2003 / 08^{++}$ & 0 & & & 0.147 & 0.072 & 0.072 & 12 & 2008/08 & $2009 / 05$ & 9 & -2.768 & -0.311 & 0.328 & 0.326 & 0.328 & (9) \\
\hline ZAC & $2003 / 04$ & 2003/08 & 4 & -1.304 & -0.328 & 0.308 & 0.175 & 0.351 & 4 & $2008 / 08$ & $2009 / 04$ & 6 & -0.866 & -0.145 & 0.472 & 0.558 & 0.312 & (3) \\
\hline
\end{tabular}

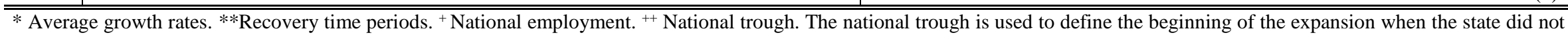
experience a fall in employment. See footnotes of Table 1 for the notation regarding early expansions.

(c) Southern Regional Science Association 2017. 
Classical Business Cycles Chronology and Regime Characteristics of Employment in the Mexican States Permanent Employment

\begin{tabular}{|c|c|c|c|c|c|c|c|c|c|c|c|c|c|c|c|c|c|c|}
\hline \multirow{4}{*}{$\frac{\text { States }}{\text { NAT }^{+}}$} & \multirow[b]{3}{*}{ Peak } & \multirow[b]{3}{*}{ Trough } & \multirow[b]{3}{*}{ Duration } & \multicolumn{2}{|l|}{2001} & & & & & \multicolumn{9}{|c|}{2008} \\
\hline & & & & \multirow[b]{2}{*}{ Depth } & \multirow[b]{2}{*}{ Steepness } & \multicolumn{4}{|c|}{ Early expansion * } & \multirow[b]{2}{*}{ Peak } & \multirow[b]{2}{*}{ Trough } & \multirow[b]{2}{*}{ Duration } & \multirow[b]{2}{*}{ Depth } & \multirow[b]{2}{*}{ Steepness } & \multicolumn{4}{|c|}{ xpansion * } \\
\hline & & & & & & EG9 & EG12 & EGR & $(* *)$ & & & & & & EG9 & EG12 & EGR & $(* *)$ \\
\hline & $2001 / 02$ & $2003 / 08$ & 30 & -2.790 & -0.094 & 0.217 & 0.209 & 0.215 & (15) & $2008 / 06$ & $2009 / 07$ & 13 & -4.475 & -0.352 & 0.272 & 0.279 & 0.292 & (16) \\
\hline AGS & 2001/02 & 2003/08 & 30 & -4.824 & -0.165 & 0.114 & 0.164 & 0.326 & (18) & $2008 / 07$ & $2009 / 08$ & 13 & -6.245 & -0.495 & 0.505 & 0.383 & 0.276 & (24) \\
\hline $\mathrm{BC}$ & $2000 / 11$ & 2003/08 & 33 & -10.127 & -0.323 & 0.627 & 0.578 & 0.428 & (27) & 2008/01 & $2009 / 07$ & 18 & -11.645 & -0.685 & 0.405 & 0.378 & 0.318 & (40) \\
\hline BCS & $2001 / 07$ & $2001 / 11$ & 4 & -2.964 & -0.749 & 0.227 & 0.201 & 0.152 & (23) & $2008 / 05$ & $2010 / 04$ & 23 & -11.292 & -0.520 & 0.089 & 0.092 & 0.223 & (33) \\
\hline CAM & & $2003 / 08^{+}$ & 0 & & & 0.383 & 0.388 & 0.388 & (12) & $2009 / 07$ & 2010/02 & 7 & -2.013 & -0.290 & 0.632 & 0.563 & 1.401 & (2) \\
\hline CHIS & & $2003 / 08^{+}$ & 0 & & & 0.337 & 0.305 & 0.305 & (12) & & $2009 / 07^{+}$ & 0 & & & 0.410 & 0.426 & 0.426 & (12) \\
\hline CHIH & $2000 / 10$ & 2003/08 & 34 & -16.126 & -0.516 & 0.174 & 0.146 & 0.090 & (113) & $2007 / 10$ & 2009/06 & 20 & -15.773 & -0.855 & 0.514 & 0.504 & 0.338 & (43) \\
\hline COA & $2000 / 11$ & 2002/03 & 16 & -5.528 & -0.355 & 0.163 & 0.055 & 0.098 & (59) & $2008 / 06$ & $2009 / 06$ & 12 & -11.259 & -0.991 & 0.704 & 0.735 & 0.709 & (17) \\
\hline COL & & $2003 / 08^{+}$ & 0 & & & 0.490 & 0.404 & 0.404 & (12) & $2008 / 07$ & 2008/09 & 2 & -1.684 & -0.845 & 0.154 & 0.137 & 0.936 & (2) \\
\hline $\mathrm{DF}$ & 2000/11 & 2003/08 & 33 & -3.018 & -0.093 & 0.157 & 0.114 & 0.151 & (22) & $2008 / 07$ & $2009 / 11$ & 16 & -5.220 & -0.335 & 0.230 & 0.257 & 0.257 & (22) \\
\hline DGO & $2000 / 11$ & $2001 / 10$ & 11 & -11.441 & -1.098 & 0.520 & 0.416 & 0.104 & (118) & 2008/01 & $2009 / 07$ & 18 & -4.505 & -0.256 & 0.358 & 0.242 & 0.278 & (17) \\
\hline GTO & & $2003 / 08^{+}$ & 0 & & & 0.138 & 0.189 & 0.189 & $(12)$ & $2008 / 07$ & 2009/05 & 10 & -2.617 & -0.265 & 0.422 & 0.427 & 0.371 & (8) \\
\hline GRO & $2001 / 04$ & $2002 / 04$ & 12 & -2.271 & -0.191 & 0.111 & 0.038 & 0.089 & (27) & $2008 / 08$ & $20010 / 09$ & 25 & -3.178 & -0.129 & 0.265 & 0.079 & 0.060 & (28) \\
\hline $\mathrm{HGO}$ & 2001/03 & 2005/09 & 54 & -8.325 & -0.161 & 0.172 & 0.249 & 0.324 & (27) & $2008 / 07$ & 2009/07 & 12 & -5.012 & -0.428 & 0.373 & 0.252 & 0.316 & (17) \\
\hline JAL & 2001/02 & $2001 / 11$ & 9 & -1.596 & -0.179 & 0.054 & 0.087 & 0.080 & (25) & $2008 / 07$ & $2009 / 08$ & 14 & -2.948 & -0.213 & 0.316 & 0.296 & 0.306 & (10) \\
\hline MEX & $2001 / 02$ & $2004 / 02$ & 36 & -3.851 & -0.109 & 0.185 & 0.187 & 0.165 & (25) & $2008 / 07$ & $2009 / 08$ & 13 & -5.061 & -0.399 & 0.232 & 0.282 & 0.300 & (18) \\
\hline $\mathrm{MICH}$ & & $2003 / 08^{+}$ & 0 & & & 0.208 & 0.254 & 0.254 & (12) & & $2009 / 07^{+}$ & 0 & & & 0.264 & 0.253 & 0.253 & (12) \\
\hline MOR & 2001/08 & 2002/11 & 15 & -1.186 & -0.080 & 0.093 & 0.129 & 0.163 & (10) & $2008 / 08$ & 2009/09 & 13 & -2.433 & -0.189 & 0.285 & 0.312 & 0.285 & (9) \\
\hline NAY & 1999/02 & $2002 / 04$ & 38 & -8.480 & -0.233 & 0.473 & 0.535 & 0.475 & (19) & $2008 / 07$ & 2009/09 & 14 & -3.470 & -0.252 & 0.644 & 0.527 & 1.081 & (4) \\
\hline NL & $2001 / 02$ & $2002 / 03$ & 13 & -2.166 & -0.168 & 0.142 & 0.117 & 0.078 & (29) & $2008 / 07$ & $2009 / 07$ & 12 & -5.753 & -0.493 & 0.464 & 0.421 & 0.429 & (14) \\
\hline OAX & & $2003 / 08^{+}$ & 0 & & & 0.120 & 0.179 & 0.179 & (12) & & $2009 / 07^{+}$ & 0 & & & 0.020 & 0.031 & 0.031 & (12) \\
\hline PUE & $2000 / 10$ & $2004 / 02$ & 40 & -8.552 & -0.223 & 0.175 & 0.174 & 0.109 & (84) & $2008 / 10$ & 2009/08 & 10 & -3.021 & -0.306 & 0.320 & 0.326 & 0.317 & (10) \\
\hline QRO & 2001/02 & 2002/01 & 11 & -1.372 & -0.126 & 0.169 & 0.198 & 0.366 & (4) & 2008/07 & 2009/07 & 12 & -5.650 & -0.483 & 0.722 & 0.697 & 0.722 & (9) \\
\hline QROO & 2001/08 & $2001 / 10$ & 2 & -4.900 & -2.481 & 0.649 & 0.418 & 0.635 & (8) & $2008 / 11$ & 2009/11 & 12 & -7.047 & -0.607 & 0.128 & 0.120 & 0.150 & (38) \\
\hline SLP & 2001/06 & 2001/09 & 3 & -1.013 & -0.339 & 0.214 & 0.246 & 0.187 & (7) & $2008 / 07$ & $2009 / 08$ & 13 & -4.251 & -0.334 & 0.491 & 0.488 & 0.491 & (9) \\
\hline SIN & 2003/01 & 2003/08 & 7 & -0.669 & -0.096 & 0.160 & 0.178 & 0.239 & (3) & 2008/09 & $2009 / 05$ & 8 & -1.337 & -0.168 & 0.186 & 0.227 & 0.186 & (9) \\
\hline SON & $2000 / 11$ & 2003/02 & 27 & -8.816 & -0.341 & 0.131 & 0.187 & 0.289 & (32) & $2008 / 04$ & 2009/05 & 13 & -7.826 & -0.625 & 0.499 & 0.525 & 0.493 & (17) \\
\hline TAB & & $2003 / 08^{+}$ & 0 & & & 0.395 & 0.504 & 0.504 & (12) & & $2009 / 07^{+}$ & 0 & & & 0.329 & 0.289 & 0.289 & (12) \\
\hline TAM & 2001/01 & 2003/08 & 31 & -5.643 & -0.187 & 0.377 & 0.356 & 0.372 & (16) & 2008/04 & $2009 / 07$ & 15 & -10.040 & -0.703 & 0.380 & 0.360 & 0.216 & (42) \\
\hline TLAX & $2000 / 10$ & $2004 / 03$ & 41 & -14.528 & -0.382 & 0.507 & 0.492 & 0.015 & (106) & $2005 / 04$ & $2009 / 08$ & 52 & -19.005 & -0.405 & 0.275 & 0.297 & 0.322 & (41) \\
\hline VER & $2001 / 11$ & $2002 / 05$ & 6 & -0.717 & -0.120 & 0.249 & 0.188 & 0.319 & (3) & 2009/07 & 2009/09 & 2 & -1.234 & -0.619 & 0.289 & 0.269 & 0.331 & (5) \\
\hline YUC & & $2003 / 08^{++}$ & 0 & & & 0.202 & 0.211 & 0.211 & (12) & $2008 / 10$ & $2009 / 06$ & 8 & -2.042 & -0.258 & 0.270 & 0.249 & 0.279 & (8) \\
\hline ZAC & 2003/01 & 2003/09 & 8 & -1.311 & -0.165 & 0.239 & 0.150 & 0.200 & (7) & $2008 / 10$ & $2009 / 04$ & 6 & -2.057 & -0.346 & 0.368 & 0.422 & 0.334 & (7) \\
\hline
\end{tabular}

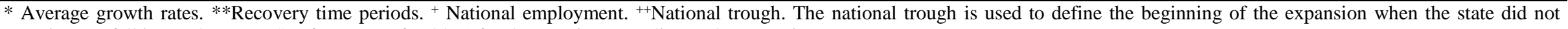
experience a fall in employment. See footnotes of Table 1 for the notation regarding early expansions. 
Classical Business Cycles Chronology and Regime Characteristics of Employment in the Mexican States

\section{Temporary Employment}

\begin{tabular}{|c|c|c|c|c|c|c|c|c|c|c|c|c|c|c|c|c|c|c|}
\hline \multicolumn{10}{|c|}{2001} & \multicolumn{9}{|c|}{2008} \\
\hline \multirow[b]{2}{*}{ States } & \multirow[b]{2}{*}{ Peak } & \multirow[b]{2}{*}{ Trough } & \multirow[b]{2}{*}{ Duration } & \multirow[b]{2}{*}{ Depth } & \multirow[b]{2}{*}{ Steepness } & \multicolumn{4}{|c|}{ Early expansion * } & \multirow[b]{2}{*}{ Peak } & \multirow[b]{2}{*}{ Trough } & \multirow[b]{2}{*}{ Duration } & \multirow[b]{2}{*}{ Depth } & \multirow[b]{2}{*}{ Steepness } & \multicolumn{4}{|c|}{ Early expansion * } \\
\hline & & & & & & EG9 & EG12 & EGR & $(* *)$ & & & & & & EG9 & EG12 & EGR ( & $(* *)$ \\
\hline $\mathrm{NAT}^{+}$ & $2000 / 07$ & $2002 / 03$ & 20 & -14.838 & -0.800 & 0.502 & 0.345 & 0.422 & (39) & $2008 / 09$ & $2009 / 05$ & 8 & -4.593 & -0.586 & 1.086 & 1.145 & 0.974 & (6) \\
\hline AGS & $2001 / 02$ & $2001 / 12$ & 10 & -8.003 & -0.831 & 0.731 & 0.524 & 2.554 & (4) & $2007 / 07$ & 2009/02 & 19 & -25.636 & -1.547 & 1.036 & 1.158 & 1.106 & (27) \\
\hline $\mathrm{BC}$ & $2000 / 06$ & $2001 / 12$ & 18 & -34.570 & -2.329 & 1.388 & 1.498 & 1.096 & (40) & 2006/12 & 2009/11 & 35 & -23.171 & -0.750 & 0.030 & 1.389 & 1.121 & (25) \\
\hline BCS & $2000 / 12$ & $2002 / 03$ & 15 & -21.876 & -1.632 & 0.599 & 0.333 & 0.988 & (27) & $2007 / 10$ & 2009/09 & 23 & -26.532 & -1.332 & 0.573 & 0.855 & 0.474 & (40) \\
\hline CAM & 1999/08 & $2000 / 04$ & 8 & -21.020 & -2.907 & 2.009 & 1.790 & 0.496 & (48) & 2009/06 & 2010/08 & 14 & -16.886 & -1.312 & 0.503 & 0.726 & 0.804 & (25) \\
\hline CHIS & $2000 / 09$ & $2001 / 10$ & 13 & -30.263 & -2.735 & 0.786 & 0.813 & 0.656 & (56) & 2006/07 & $2008 / 04$ & 21 & -30.345 & -1.707 & 1.406 & 1.179 & 1.143 & (32) \\
\hline $\mathrm{CHIH}$ & $2000 / 06$ & $2002 / 03$ & 21 & -24.671 & -1.340 & 1.166 & 1.085 & 1.352 & (24) & $2007 / 08$ & 2009/05 & 21 & -23.450 & -1.264 & 2.753 & 2.608 & 2.512 & (11) \\
\hline $\mathrm{COA}$ & $2000 / 11$ & 2003/09 & 34 & -23.929 & -0.801 & 0.865 & 0.768 & 1.015 & (28) & 2008/07 & 2009/05 & 10 & -11.454 & -1.209 & 1.647 & 1.806 & 2.151 & (6) \\
\hline COL & $2002 / 04$ & $2003 / 03$ & 11 & -16.330 & -1.608 & 0.798 & 0.539 & 0.366 & (49) & $2007 / 04$ & 2009/05 & 25 & -16.505 & -0.719 & 2.445 & 2.171 & 4.625 & (4) \\
\hline $\mathrm{DF}$ & $2000 / 07$ & $2001 / 04$ & 9 & -12.266 & -1.443 & 0.868 & 0.654 & 0.400 & (35) & & $2009 / 05^{+}$ & 0 & & & 0.918 & 0.980 & 0.980 & (12) \\
\hline DGO & 1999/11 & $2003 / 05$ & 42 & -18.359 & -0.482 & 2.092 & 1.462 & 2.177 & (10) & 2007/11 & 2008/11 & 12 & -14.797 & -1.326 & 0.915 & 0.862 & 1.177 & (14) \\
\hline GTO & $2000 / 07$ & 2003/12 & 41 & -17.059 & -0.455 & 0.588 & 0.592 & 0.736 & (26) & $2008 / 04$ & 2009/05 & 13 & -5.362 & -0.423 & 1.381 & 1.230 & 1.436 & (6) \\
\hline GRO & $2000 / 06$ & $2001 / 12$ & 18 & -23.538 & -1.480 & 0.845 & 0.670 & 1.009 & (27) & 2008/05 & $2011 / 11$ & 42 & -15.163 & -0.391 & 0.075 & 0.420 & 0.311 & (14) \\
\hline HGO & $2000 / 12$ & $2002 / 05$ & 17 & -20.648 & -1.351 & 1.831 & 1.667 & 1.895 & (13) & $2008 / 10$ & $2009 / 10$ & 12 & -16.461 & -1.488 & 1.084 & 1.354 & 1.483 & (13) \\
\hline JAL & $2000 / 07$ & $2001 / 12$ & 17 & -17.161 & -1.101 & 0.891 & 0.855 & 0.433 & (47) & 2008/02 & $2009 / 04$ & 14 & -7.186 & -0.531 & 1.298 & 1.336 & 1.372 & (6) \\
\hline MEX & $2000 / 07$ & $2002 / 12$ & 29 & -18.432 & -0.700 & 0.523 & 0.455 & 0.624 & (36) & 2008/09 & 2009/05 & 8 & -4.084 & -0.520 & 1.423 & 1.601 & 1.088 & (4) \\
\hline MICH & $1998 / 05$ & 1999/02 & 9 & -14.815 & -1.766 & 1.627 & 1.517 & 1.558 & (11) & 2008/04 & 2009/01 & 9 & -4.711 & -0.535 & 0.917 & 0.926 & 3.995 & (2) \\
\hline MOR & 1999/12 & $2000 / 05$ & 11 & -24.471 & -2.519 & 2.049 & 0.951 & 0.727 & (39) & $2006 / 10$ & 2008/08 & 12 & -8.549 & -0.742 & 0.017 & 0.582 & 0.705 & (13) \\
\hline NAY & & $2002 / 03^{++}$ & 0 & & & 0.443 & 1.456 & 1.456 & (12) & $2006 / 10$ & 2009/05 & 31 & -27.351 & -1.025 & 1.632 & 1.205 & 0.589 & (44) \\
\hline NL & 1999/09 & 2002/03 & 30 & -30.881 & -1.224 & 1.392 & 1.193 & 0.742 & (52) & 2008/09 & $2009 / 05$ & 8 & -10.283 & -1.347 & 0.239 & 0.556 & 1.604 & (8) \\
\hline OAX & 1998/08 & $1999 / 10$ & 14 & -15.961 & -1.234 & 0.847 & 0.661 & 0.195 & (96) & 2006/03 & 2006/11 & 8 & -14.921 & -2.000 & 1.205 & 1.414 & 1.653 & (11) \\
\hline PUE & $2000 / 03$ & 2003/05 & 38 & -18.089 & -0.524 & 1.173 & 1.078 & 1.007 & (20) & 2008/09 & 2009/02 & 5 & -7.255 & -1.495 & 0.841 & 1.031 & 0.841 & (9) \\
\hline QRO & $2000 / 07$ & $2001 / 07$ & 12 & -22.181 & -2.068 & 1.328 & 1.726 & 0.759 & (38) & 2008/09 & 2009/06 & 5 & -9.330 & -1.940 & 0.962 & 1.176 & 1.071 & (10) \\
\hline QROO & 1998/11 & $2002 / 05$ & 42 & -52.466 & -1.755 & 3.157 & 2.517 & 2.185 & (35) & $2008 / 07$ & 2009/06 & 11 & -21.106 & -2.132 & 2.745 & 2.359 & 2.745 & (9) \\
\hline SLP & $2000 / 07$ & $2000 / 12$ & 5 & -20.556 & -4.498 & 1.440 & 1.402 & 1.234 & (19) & $2008 / 05$ & $2009 / 10$ & 17 & -14.226 & -0.899 & 1.441 & 1.579 & 1.638 & (11) \\
\hline SIN & 1999/03 & $2004 / 02$ & 59 & -39.009 & -0.835 & 2.327 & 1.590 & 1.185 & (42) & 2008/11 & 2009/06 & 7 & -20.224 & -3.176 & 2.011 & 1.030 & 0.779 & (30) \\
\hline SON & $2000 / 06$ & 2003/02 & 32 & -29.259 & -1.076 & 0.975 & 0.059 & 1.566 & (23) & $2007 / 01$ & 2009/08 & 31 & -18.420 & -0.655 & 1.336 & 0.655 & 0.917 & (23) \\
\hline TAB & $2000 / 08$ & $2002 / 03$ & 19 & -21.411 & -1.260 & 2.311 & 1.931 & 2.474 & (10) & $2008 / 06$ & $2008 / 10$ & 4 & -10.147 & -2.639 & 0.386 & 0.579 & 0.553 & (25) \\
\hline TAM & $2000 / 09$ & $2004 / 02$ & 41 & -25.050 & -0.701 & 0.841 & 0.996 & 0.694 & (44) & 2008/05 & 2009/12 & 19 & -10.458 & -0.580 & 0.959 & 0.657 & 0.457 & (25) \\
\hline TLAX & 1999/05 & $2002 / 11$ & 42 & -49.070 & -1.594 & 1.786 & 2.004 & 1.056 & (65) & 2008/12 & $2009 / 07$ & 7 & -10.294 & -1.540 & 3.227 & 3.227 & 3.163 & (4) \\
\hline VER & $2000 / 10$ & $2004 / 05$ & 43 & -26.431 & -0.711 & 0.874 & 0.302 & 0.538 & (58) & 2007/08 & 2007/12 & 4 & -11.770 & -3.082 & 1.087 & 0.795 & 0.920 & (15) \\
\hline YUC & $2000 / 01$ & 2002/09 & 32 & -30.662 & -1.138 & 0.835 & 0.953 & 0.678 & (57) & $2007 / 10$ & $2009 / 05$ & 19 & -23.082 & -1.372 & 1.496 & 1.539 & 1.391 & (21) \\
\hline ZAC & $2001 / 05$ & $2002 / 07$ & 14 & -16.097 & -1.246 & 1.155 & 0.556 & 0.958 & (19) & $2007 / 11$ & 2008/01 & 2 & -6.715 & -3.416 & 1.369 & 1.384 & 1.314 & (6) \\
\hline
\end{tabular}

experience a fall in employment. See footnotes of Table 1 for the notation regarding early expansions.

(c) Southern Regional Science Association 2017. 